\title{
KATIAN (UPPER ORDOVICIAN) CONODONTS FROM WALES
}

\author{
ANNALISA FERRETTI ${ }^{*}$, STIG M. BERGSTRÖM ${ }^{2}$ and CHRISTOPHER R. BARNES ${ }^{3}$ \\ ${ }^{1}$ Dipartimento di Scienze Chimiche e Geologiche, l.go S. Eufemia 19, 41121 Modena, Italy; e-mail: ferretti@unimore.it \\ ${ }^{2}$ Division of Earth History, School of Earth Sciences, The Ohio State University, 125 S. Oval Mall, Columbus, OH 43210, USA; e-mail: bergstrom.1@osu.edu \\ ${ }^{3}$ School of Earth and Ocean Sciences, University of Victoria, PO Box 1700, Victoria, BC Canada, V8W 2Y2; e-mail: crbarnes@uvic.ca \\ ${ }^{\star}$ Corresponding author \\ Typescript received 3 July 2013; accepted in revised form 4 November 2013
}

\begin{abstract}
Middle and upper Katian conodonts were previously known in the British Isles from relatively small collections obtained from a few localities. The present study is mainly based on 17 samples containing more than 17000 conodont elements from an approximately 14 -m-thick succession of the Sholeshook Limestone Formation in a road cut near Whitland, South Wales, that yielded a diverse fauna of more than 40 taxa. It is dominated by representatives of Amorphognathus, Aphelognathus/Plectodina and Eocarniodus along with several coniform taxa. Representatives of Decoriconus, Istorinus and Sagittodontina are reported from the Ordovician of UK for the first time. The fauna is a typical representative of the British Province of the Atlantic Realm and includes a mixture of taxa of North American, Baltoscandic and Mediterranean affinities along with pandemic species. Based on the presence of many elements of Amorphognathus ordovicicus and some morphologically advanced specimens of Amorphognathus superbus, the Sholeshook Limestone Formation is referred to the lower A. ordovicicus
\end{abstract}

Zone. Most of the unit is also coeval with Zone 2 of the Cautleyan Stage in the British regional stage classification, and stage slice Ka3 of the middle Katian Stage in the global stratigraphical classification, an age assignment consistent with data from trilobites, graptolites and chitinozoans. The unusually large collection of $\mathrm{M}$ elements of Amorphognathus provides insight into the complex morphological variation in this element of some Katian species of this genus. The Sholeshook conodont fauna is similar to those of the Crûg and Birdshill limestones, but differs in several respects from the slightly older ones from the Caradocian type area in the Welsh Borderland. Although having some species in common, the Sholeshook conodont fauna clearly differs from coeval Baltoscandic faunas and is even more different in composition compared with equivalent North American Midcontinent faunas.

Key words: Ordovician, Katian, conodonts, biostratigraphy, taxonomy, Wales, Amorphognathus evolution.
Compared to that of some other Upper Ordovician key regions, such as the North American Midcontinent, Baltoscandia and China, the literature of British Sandbian and Katian conodonts is rather limited and comprehensive investigations are presented in only a few publications. The principal reason for this limited study is likely to be the fact that calcareous rocks suitable for acid digestion of conodont samples are subordinate in the dominantly clastic successions of this age in the British Isles. The calcareous intervals that do occur locally are rather thin, which makes it impossible to collect samples through thick stratigraphic intervals in a single section as can be done in, for instance, Baltoscandia and the North American Midcontinent. However, as shown by, for instance, Rhodes (1953, 1955), Lindström (1959), Bergström (1964, 1971a), Orchard (1980), Savage and Bassett (1985) and Bergström et al. (1987), local carbonate intervals may produce moderately abundant and reasonably well-preserved conodonts of considerable taxonomic and biostratigraphic significance.

This paper deals with the unusually abundant and unexpectedly diverse, but previously undescribed, conodont fauna from the regionally and stratigraphically restricted Sholeshook Limestone Formation (hereafter referred to as the Sholeshook Limestone) in South Wales. It demonstrates that conodont studies of limited stratigraphic and geographical scope can give results of both local and international significance.

During the last two decades, a new global series and stage classification of the Ordovician has been introduced (Bergström et al. 2009), and also, the regional classification and correlation of this system in the UK have undergone substantial changes, some of which are not dealt with in the indispensable general reviews such as Fortey et al. $(1995,2000)$. Furthermore, because the present study includes not only regions in the UK but also 


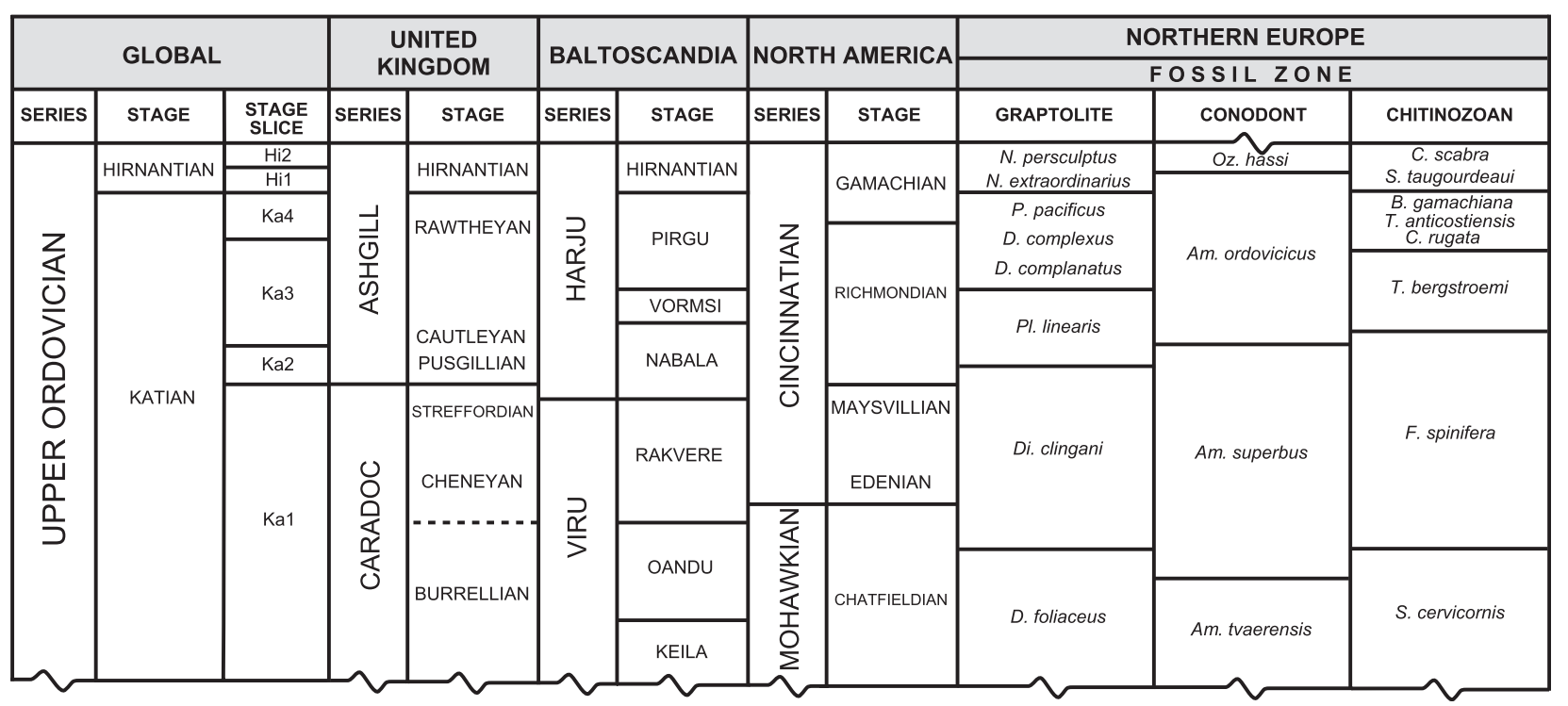

FIG. 1. Correlation between global series, stages and stage slices (after Bergström et al. 2009), and for regional stratigraphic units in the UK, Baltoscandia and North America. Also shown are the inferred relationships between these units and North European graptolite, conodont and chitinozoan zones. N, Normalograptus; P, Paraorthograptus; D, Dicellograptus; Pl, Pleurograptus; Di, Dicranograptus; Oz, Ozarkodina; Am, Amorphognathus; C, Conochitina; S, Spinachitina; B, Belonechitina; T, Tanuchitina; F, Fungochitina.

considers areas in Baltoscandia and North America and deals with a substantial number of lithostratigraphic and chronostratigraphic units, we illustrate in Figure 1 our interpretation of the correlations between pertinent Katian and Hirnantian chronostratigraphic units and their relations to graptolite, conodont and chitinozoan zones. Although some relationships are not yet firmly established, we believe that this figure provides a reasonably up-to-date illustration of the classification and correlation of the stratigraphic units discussed in the present study.

\section{PREVIOUSLY DESCRIBED KATIAN AND HIRNANTIAN CONODONT FAUNAS FROM THE UK}

Several Katian conodont occurrences have been described in the Welsh Borderland and in Wales (Rhodes 1953; Lindström 1959; Bergström 1964, 1971a; Orchard 1980; Savage and Bassett 1985), the best known being those of the Crûg and Birdshill limestones of the Llandeilo area and the Cymerig Limestone (formerly known as the Peny-garnedd and Gelli-grin limestones) of the Bala area in North Wales. The conodont fauna of the latter shelly unit includes Amorphognathus superbus, indicating that it represents the A. superbus Zone, which is of early Katian age (stage slices Ka1 and Ka2 of Bergström et al. 2009).

Middle and upper Katian conodont faunas are relatively well studied in northern England and include those of the Keisley Limestone (Rhodes 1955; Orchard 1980; Sweet and Bergström 1984) and various Ashgillian locali- ties in the Lake District (Orchard 1980). In southern Scotland, Katian faunas include that of the Shalloch Formation of the Girvan area (Bergström 1990). A few Hirnantian species records are from the Hartfell Shales at Dob's Linn north of Moffat (Barnes and Williams 1988). For additional information about British Upper Ordovician conodont occurrences, see Bergström and Orchard (1985).

\section{STUDY LOCALITIES AND CONODONT COLLECTIONS}

Although the present study is based on new conodont collections from three localities in South Wales and one in North Wales (Fig. 2), it is centred on those from the impressive road cut along the A40 approximately $3 \mathrm{~km}$ west of Whitland in South Wales, which is known as the Whitland section. For particulars about this outcrop, see Zalasiewicz et al. (1995). In this exposure (Figs 3-5), which is probably the most extensive outcrop through the middle Katian in Wales, the basal $20 \mathrm{~m}$ of the exposed succession consists of dark grey laminated shale that was previously known as the Dicranograptus Shales but is now referred to as the Mydrim Shales (Fortey et al. 2000). At the Whitland section, this unit has yielded important lower Katian (stage slice Kal) graptolite faunas (Zalasiewicz et al. 1995) and biostratigraphically diagnostic chitinozoans (Vandenbroucke et al. 2008). According to Zalasiewicz et al. (1995), the graptolites from the top $18 \mathrm{~m}$ of the Mydrim Shales do not include biostrati- 


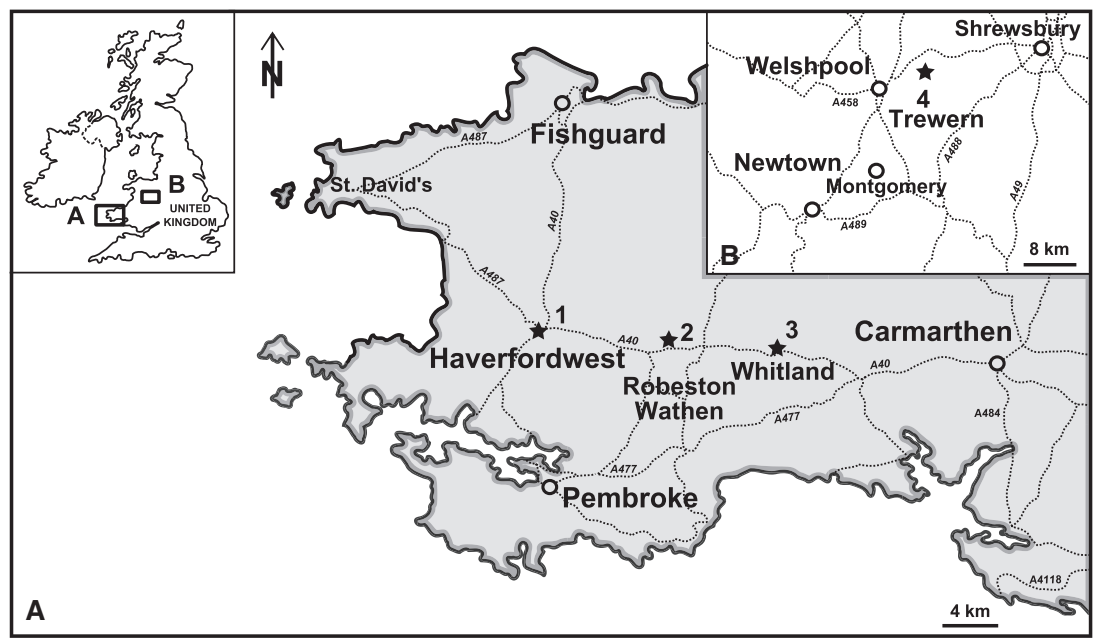

FIG. 2. Sketch maps of Wales showing location of conodont localities mentioned in the text. A, localities 1-3 in South Wales. Locality 1 is the type locality of the Sholeshook Limestone in the railroad cut $1.5 \mathrm{~km}$ north-east of Haverfordwest, Pembrokeshire (National Grid Reference SM 9681 1705). Locality 2 is the type locality of the Robeston Wathen Limestone $0.5 \mathrm{~km}$ north of Robeston Wathen, Pembrokeshire (National Grid Reference SN 0841 1615). Locality 3 is the Whitland road cut along the A40 c. $3 \mathrm{~km}$ west of Whitland (National Grid Reference between SN 16971599 and SN 1713 1598; Whitland Lat. 51.81941, Long. -4.61456). The Crûg and Birdshill localities are situated near Llandeilo c. $20 \mathrm{~km}$ east of Carmarthen. B, location of the Trewern outcrop c. $7 \mathrm{~km}$ north-east of Welshpool, Montgomeryshire, north-central Wales (National Grid Reference SJ 287 107; WGS84 coordinates 52 $39^{\prime} 34.78^{\prime \prime} \mathrm{N}, 3^{\circ} 8^{\prime} 50.1^{\prime \prime} \mathrm{W}$ ).

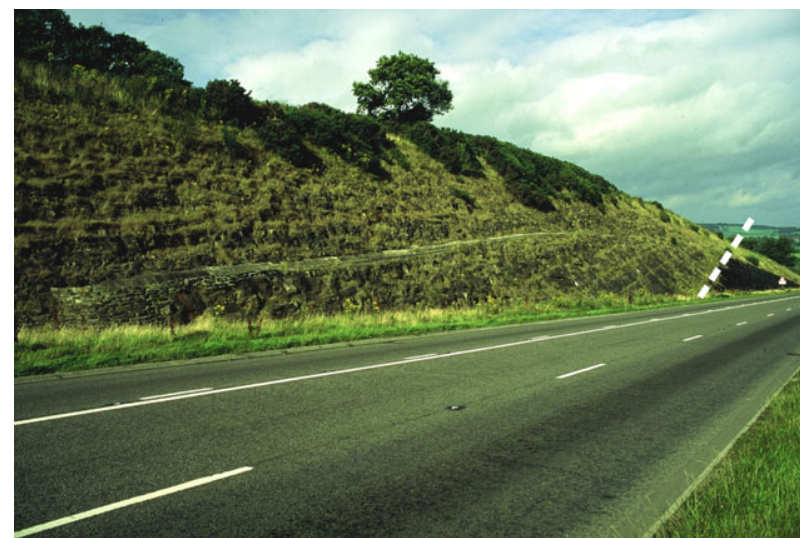

FIG. 3. The Whitland A40 section. Broken line shows the contact between the dark Mydrim Shales and the overlying Sholeshook Limestone. Photograph by CRB.

graphically diagnostic species, but they referred this interval tentatively to the Pleurograptus linearis Zone. These strata are underlain by an approximately 16.5-m-thick succession of Mydrim Shales that contains a taxonomically diverse graptolite fauna representing the Dicranograptus clingani Zone (upper part of stage slice Ka1).

In the Whitland section, the Mydrim Shales is overlain by an approximately 14-m-thick interval of impure lenticular limestone and shale referred to as the Sholeshook Limestone (Figs 3-4). The basal contact of this unit is well marked lithologically, but there is a gradational lithological transition from dominating shale to limestone over approximately $1 \mathrm{~m}$ (Fig. 5). The macrofauna of the Sholeshook Limestone includes mainly shelly fossils, such as trilobites (Price 1973, 1977, 1980, 1984), brachiopods and corals (Baars, 2013). The few graptolites recorded from the Sholeshook Limestone at a nearby section (Strahan et al. 1914; Zalasiewicz et al. 1995) are difficult to classify in terms of standard graptolite zones.

The Sholeshook Limestone is overlain by a significant thickness (c. $100 \mathrm{~m})$ of relatively poorly fossiliferous, dominantly clastic, sediments classified as the Slade and Redhill Formation (Fortey et al. 2000). This unit is considered to be of latest Katian (Rawtheyan) age (Price 1984; Fortey et al. 2000) based on shelly fossils.

The lithological change from the relatively shallowwater Sholeshook Limestone with a shelly fauna into the poorly fossiliferous mudstone of the locally several hundred-metre-thick Slade and Redhill Formation is of regional interest. We are not aware of any detailed sedimentological study of the latter unit in the Whitland section, but Brenchley et al. (2006) suggested that this formation in the Tywi Anticline region to the east-southeast of Whitland was deposited in relatively deep water in an outer shelf to slope environment. If this interpretation applies to the Whitland area, this deepening event would be at least broadly coeval with a transgressive event known from wide regions in Baltoscandia, the North American Midcontinent and elsewhere. In the former region, the shallow-water Slandrom Limestone in Sweden and the Saunja Formation in the East Baltic are overlain by the deeper-water black graptolite shale known as the Fjäcka 


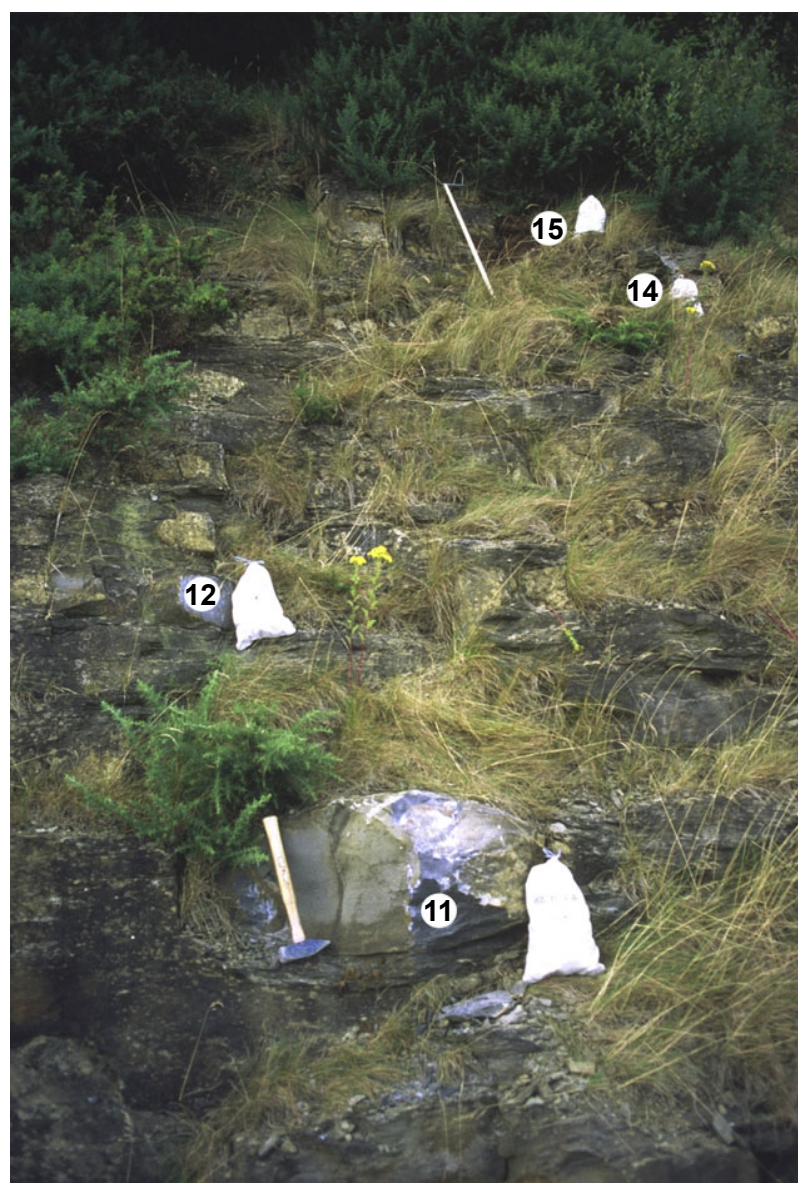

FIG. 4. Typical lithology of the Sholeshook Limestone in the Whitland section. White bags mark position of samples from large concretions and lenticular limestone beds in the upper half of the Sholeshook Limestone. For scale, the hammer is $38 \mathrm{~cm}$ long. Photograph by CRB.

Shale that has graptolites of the upper P. linearis Zone and represents the lower A. ordovicicus Conodont Zone. In the Oslo region of Norway, the corresponding deeper-water unit is the Venstøp Formation, which rests unconformably on the Solvang Formation (Bergström et al. 2011a, fig. 10). In the North American Midcontinent, for instance, in Iowa of the Upper Mississippi Valley, the Dubuque Formation is overlain by the graptolite-bearing Maquoketa Shale. Bergström et al. $(2011 a, b, 2012)$ recognized the apparent eustatic nature of this event that based on Norwegian sections was named the Linearis Drowning Event by Nielsen (2004). The fact that this sea-level rise is recognizable in not only the Whitland outcrop but also in other successions in South Wales provides support for the interpretation that this sea-level change was not only local but of global nature.

Seventeen conodont samples were collected through the Sholeshook Limestone and six from the Slade and Redhill Formation (Fig. 5). Although Rhodes (1953) failed to find any conodonts in samples from the Sholeshook Limestone in its reference section in the railway cutting at Sholeshook, standard acetic acid treatment of our much larger samples from the Whitland section produced about 17000 conodont elements. This is likely to be the largest conodont collection obtained from any Ordovician unit in the British Isles. The conodont elements have a CAI value of 5, indicating that burial temperatures corresponding to $300-400^{\circ} \mathrm{C}$ (Epstein et al. 1977), are commonly small and fragmentary, but otherwise the state of preservation of the elements is relatively good. The heavy residues also contained pyritized chitinozoans, ostracodes, brachiopods, gastropods, sponge spiculae and bivalves.

\section{COMPOSITION OF THE SHOLESHOOK LIMESTONE CONODONT FAUNA}

We distinguish more than 40 conodont taxa (see Ferretti et al. 2013) in our samples from the Whitland section. Among these taxa, 21 are identified to multielement species, 12 are classified in open nomenclature, 11 are not identified to multielement species level, two are identified with question, and two are referred to as form species. The stratigraphical ranges of most significant conodont taxa through the Sholeshook Limestone are shown in Figure 6.

The Whitland conodont collection exhibits little change in composition and species abundance through the 14-mthick Sholeshook Limestone. Numerically dominating taxa are representatives of Amorphognathus (31\%), Plectodina/Aphelognathus (15\%) and Eocarniodus (27\%) that include more than two-thirds of the total number of elements in our collection. Less common taxa are Birksfeldia circumplicata (2\%), Dapsilodus mutatus (4\%), Drepanoistodus suberectus (1.3\%), Panderodus spp. (4\%), Rhodesognathus elegans (2\%) and Scabbardella altipes $(2 \%)$. Rare taxa, present in an abundance of less than 1.5 per cent, include mainly Hamarodus brevirameus $(0.8 \%)$, Icriodella superba (0.6\%), Ozarkodina pseudofissilis (0.1\%), Pseudooneotodus spp. (0.3\%), Sagittodontina sp. $(0.05 \%)$, Venoistodus venustus $(0.5 \%)$ and Walliserodus (1.1\%). Representatives of the rare genera Decoriconus, Istorinus and Sagittodontina have previously not been recorded from the Anglo-Welsh area.

\section{BIOSTRATIGRAPHY OF THE SHOLESHOOK LIMESTONE}

As has been shown in previous studies of British Katian conodont faunas (Bergström 1964, 1971a, b; Orchard 1980; Bergström and Orchard 1985; Savage and Bassett 
FIG. 5. Schematic stratigraphic column of the Sholeshook Limestone and adjacent strata in the Whitland section. Measurements (in metres) on the left of the column are for the entire Whitland section. The numbers show levels of some conodont samples; the gap shown in the Slade and Redhill Formation marks a long covered interval.

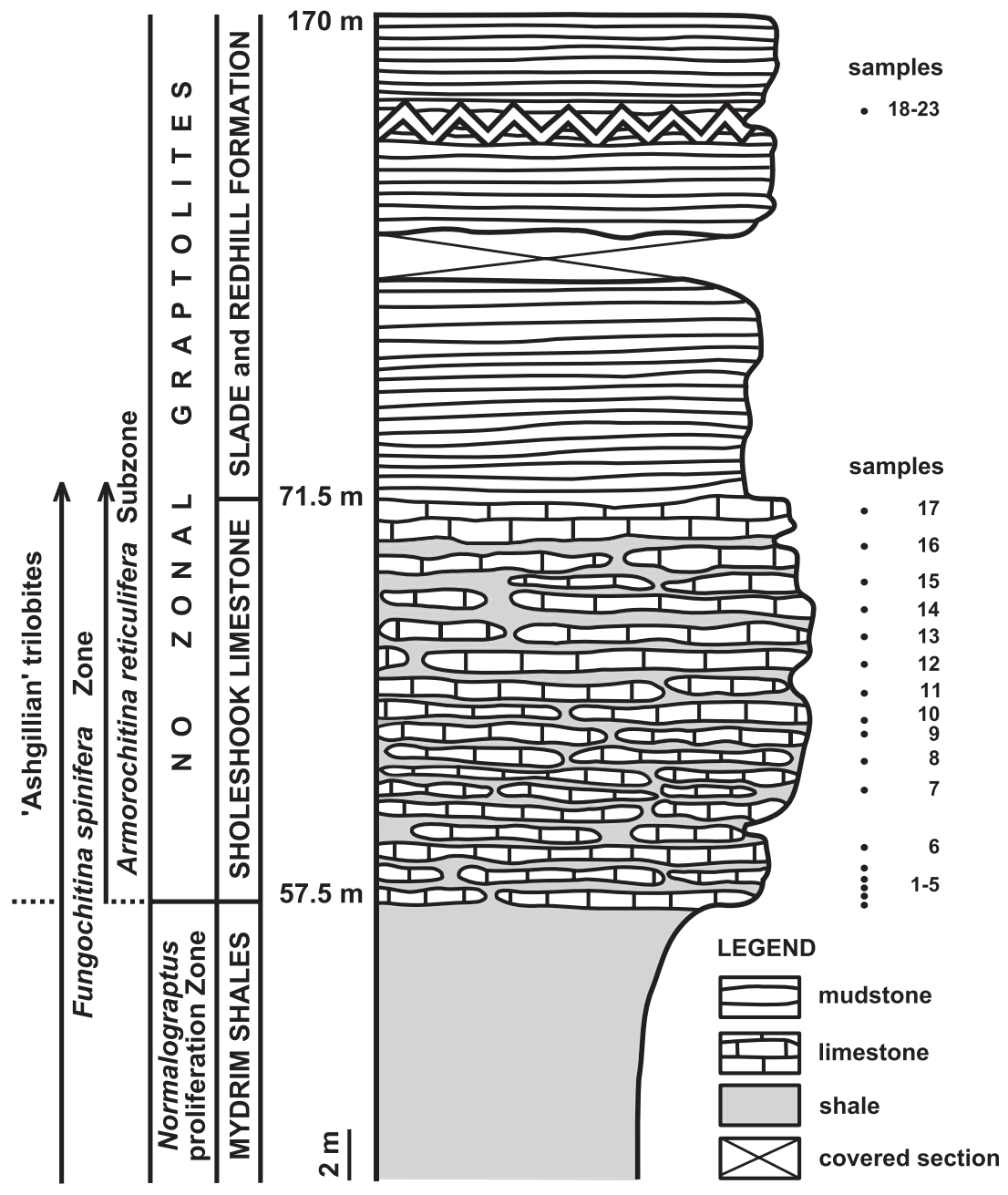

1985), the regional conodont zone classification introduced for the Middle and Upper Ordovician by Bergström $(1971 a)$ is readily applicable in the UK, especially as index species of Amorphognathus are widely distributed. This applies also to the Sholeshook Limestone succession, where a great number of $\mathrm{M}$ elements have been recovered (Fig. 7). The fact that $A$. ordovicicus co-occurs with very small numbers of $A$. superbus, its presumed ancestor, in the lower portion of the Sholeshook Limestone indicates that this formation is referable to the lower part of the A. ordovicicus Zone. This is consistent with the fact that co-occurrences of these species are known elsewhere in the basalmost A. ordovicicus Zone, for instance, in the Richmondian of Ohio (Bergström and MacKenzie 2005), the topmost Dubuque Formation of the Upper Mississippi Valley (see below) and the lower portion of the Cape Limestone of Missouri (SMB, unpubl. data).

As indicated above, the few graptolites known from the Sholeshook Limestone do not provide firm evidence of a specific graptolite zone. However, the base of the A. ordovicicus Zone in Sweden is in the uppermost Slan- drom Limestone just below the base of the Fjäcka Shale (Bergström 2007), which contains graptolites of the upper Pleurograptus linearis Zone (Skoglund 1963).

Recent chitinozoan studies of the Whitland section by Vandenbroucke et al. (2008), although based on only a small number of samples, suggest that the basal few metres of the Sholeshook Limestone belong to the Fungochitina spinifera Zone. According to Nõlvak and Grahn (1993) and Grahn and Nõlvak (2010), this chitinozoan zone typically ranges through the Baltoscandic Rakvere and Nabala regional stages that correspond to the lower part of the P. linearis Zone (Fig. 1). The next higher chitinozoan zone, the Tanuchitina bergstroemi Zone within the Baltoscandic Vormsi Stage, is associated with graptolites of the upper P. linearis Zone (Grahn and Nõlvak 2010). This chitinozoan zone has not been recorded in the Whitland succession, but Vandenbroucke et al. (2008) identified it with question from the Cardigan area of south-west Wales, where it is present in a stratigraphic interval referred to the $P$. linearis Zone. Hence, it seems likely that the Sholes- 


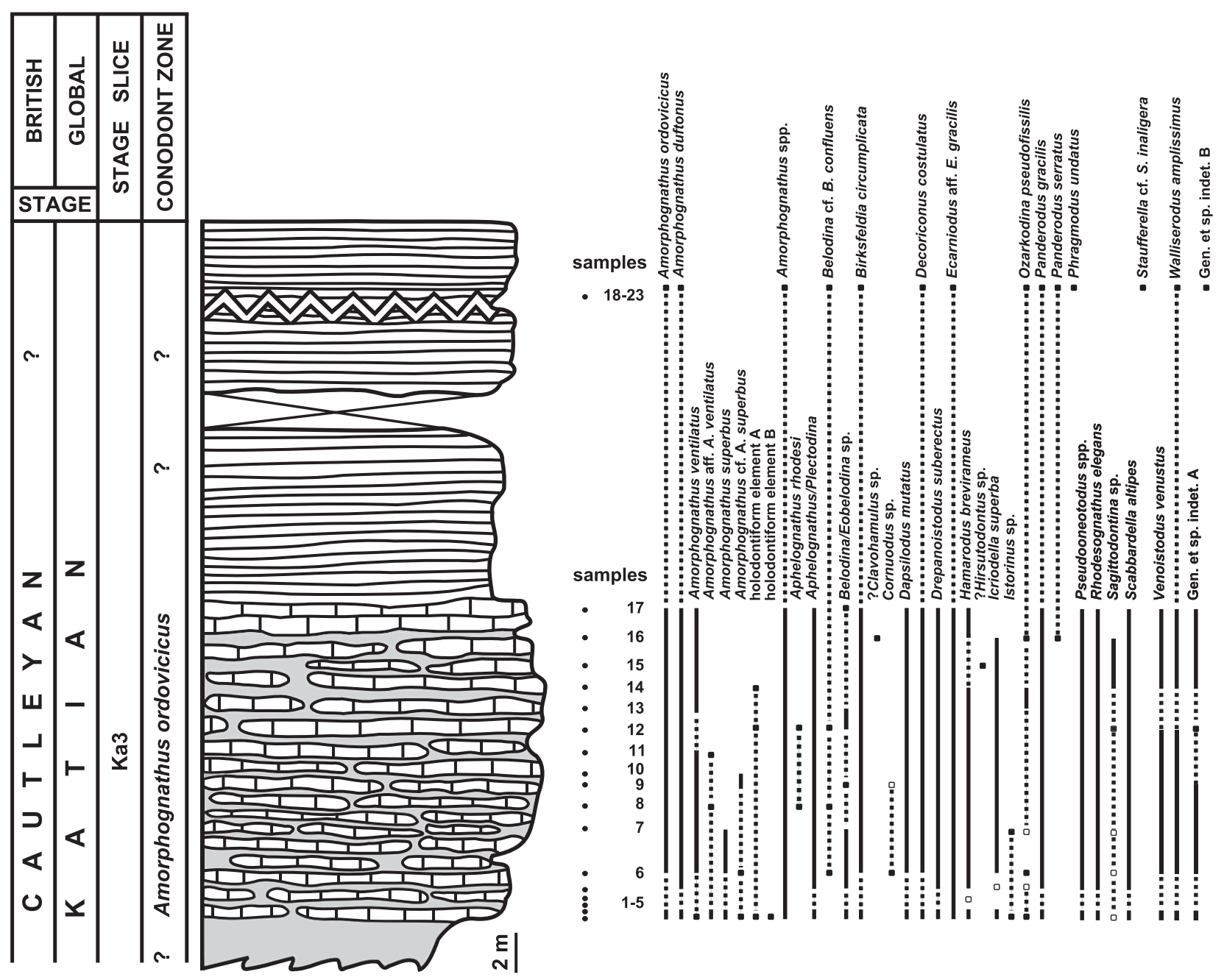

FIG. 6. Lithostratigraphy of the succession exposed at the Whitland A40 road cut and vertical ranges of main conodont taxa. White squares indicate taxa identified with question (for legend, see Figure 5).

hook Limestone corresponds to an as yet undetermined part of the P. linearis Zone.

It is also biostratigraphically significant that the trilobite Tretaspis moeldensis moeldensis, a species characteristic of the upper Pusgillian and lower Cautleyan stages in England, has been recorded by Price (1973, 1977, 1980, 1984) from the lower Sholeshook Limestone in other sections in South Wales, and a closely similar, if not identical, form has been collected also from the unit at Whitland (Zalasiewicz et al. 1995). Based on this and other trilobites, Price (1980) suggested that the Sholeshook Limestone ranges in age from the topmost Zone 1 to Zone 5 of the regional Cautleyan Stage. This is in broad agreement with the evidence from conodonts and chitinozoans.

A few samples from the Slade and Redhill Formation that overlies the Sholeshook Limestone at Whitland (Fig. 5) have produced a conodont collection of about
300 specimens. Because this fauna is dominated by Phragmodus undatus and also contains small numbers of Plectodina sp. and Belodina confluens, its composition shows a provincial affinity with coeval faunas from the North American Midcontinent. However, our Slade and Redhill conodont collection contains no biostratigraphically highly diagnostic specimens so its age within the Katian Stage remains uncertain. Hence, this conodont collection is not useful for clarifying the total chronostratigraphic range of the Sholeshook Limestone.

\section{COMPARISONS AND PROVINCIAL AFFINITES OF THE SHOLESHOOK LIMESTONE CONODONT FAUNA}

Small conodont collections obtained from the Sholeshook Limestone at Haverfordwest, the Robeston Wathen Lime- 


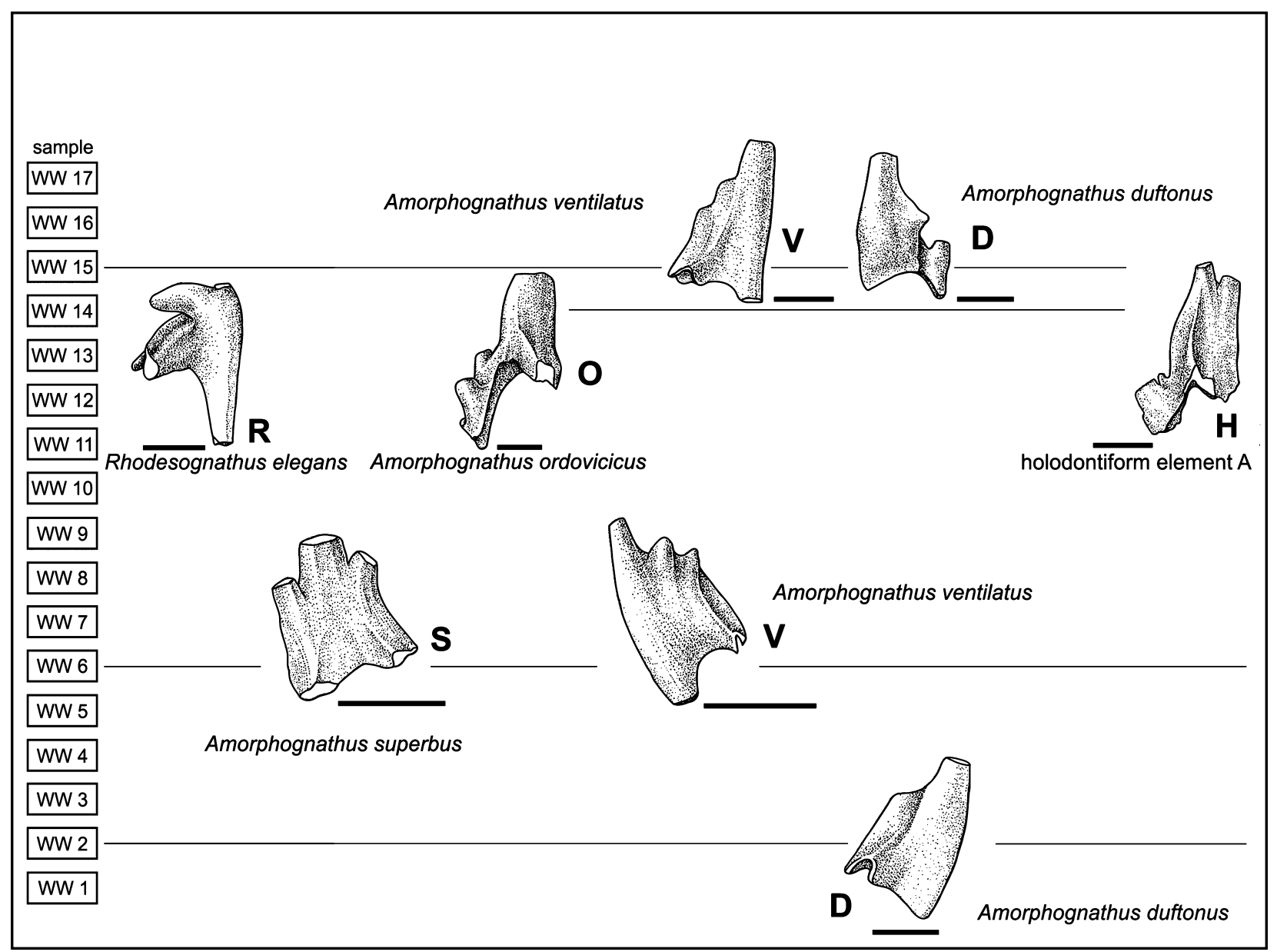

FIG. 7. Morphological types of M elements in the Sholeshook Limestone collections. Thin horizontal lines indicate sample in which illustrated specimens were found. Scale bars represent $100 \mu \mathrm{m}$.

stone at its type locality and the Nod Glas Formation at Trewern near Welshpool (for locations, see Fig. 2) contain Amorphognathus ordovicicus, but A. superbus appears to be absent from these units. These formations are not older than the A. ordovicicus Zone, and it is possible that they at least in part might be slightly younger than the Whitland development of the Sholeshook Limestone.

Apart from the Sholeshook and Robeston Wathen limestones, there are several named local carbonate units in South Wales, the most well known being the Crûg and Birdshill limestones. Because the conodonts of these formations suggest that they are at least broadly equivalent to the Sholeshook Limestone, it is of interest to compare the conodont faunas of these units with that of the Sholeshook Limestone.

\section{Crûg Limestone}

This unit is known from rather limited outcrops at Crûg Farm, which is located c. $0.8 \mathrm{~km}$ north of Llandeilo,
Carmarthenshire. For locality description, see Williams (1953) and Lindström (1959). The Crûg Limestone conodont fauna was first described by Lindström (1959), and additional records and discussions have been provided by Bergström (1964, 1971a), Orchard (1980, 1985) and Savage and Bassett (1985). For a graphic comparison of the general composition of the faunas in the Sholeshook Limestone and the Crûg Limestone see Figure 8.

Lindström (1959) identified fragmentary platform elements as Amorphognathus cf. ordovicica, but did not record any $\mathrm{M}$ elements of Amorphognathus. Such elements were found by Bergström (1971a), who identified them as A. superbus. Orchard (1980, pl. 4, fig. 21) recorded his illustrated $\mathrm{M}$ element as $A$. aff. superbus and noted that some of his $\mathrm{M}$ specimens were transitional to those of A. ordovicicus. The Crûg specimen illustrated by Savage and Bassett (1985, pl. 84, figs 15-16) was listed as A. ordovicicus, and we agree with this identification. No information is available about the collecting levels for these specimens within the Crûg Limestone, but the presence of both A. ordovicicus and A. superbus within this 
rather thin unit suggests that it represents an interval in the lowermost A. ordovicicus Zone although it is possible that the lower portion of the Crûg Limestone belongs to the A. superbus Zone. As a whole, the Crûg Limestone conodont fauna is quite similar to that of the Sholeshook Limestone, which suggests that these carbonate units do

A

SHOLESHOOK

B

CAUTLEY

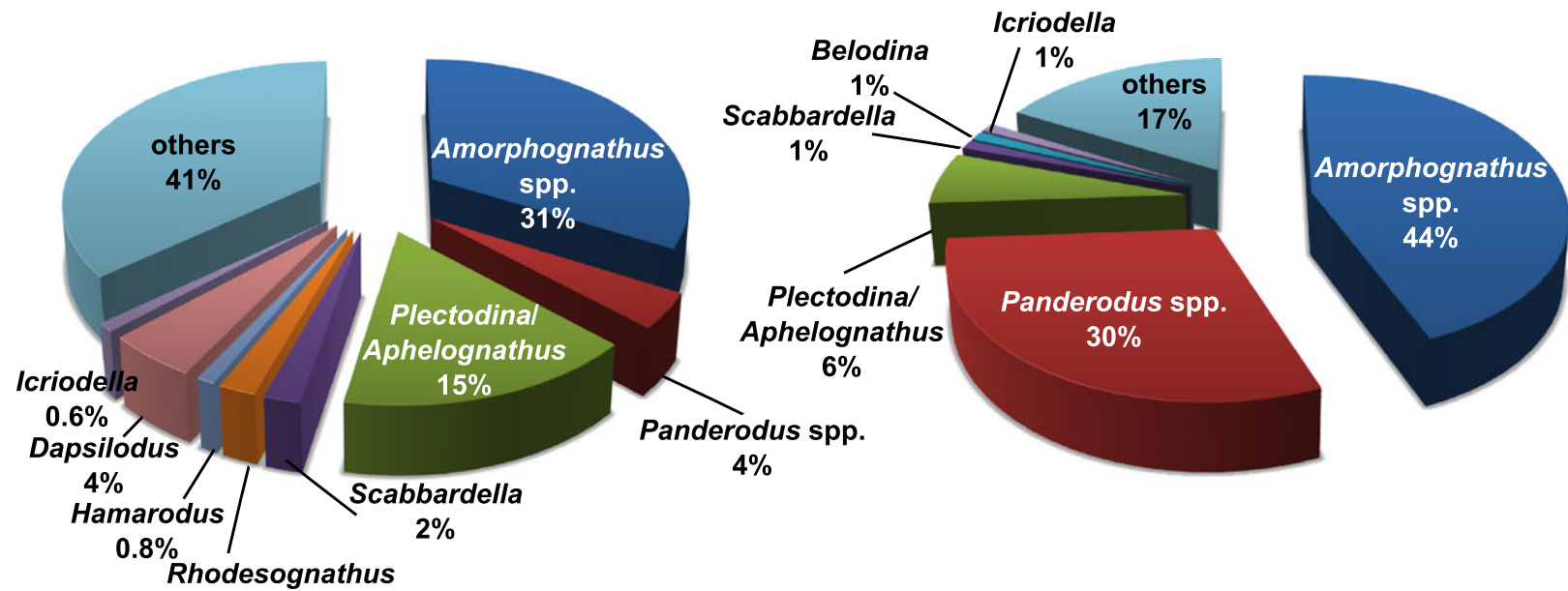

$2 \%$

C

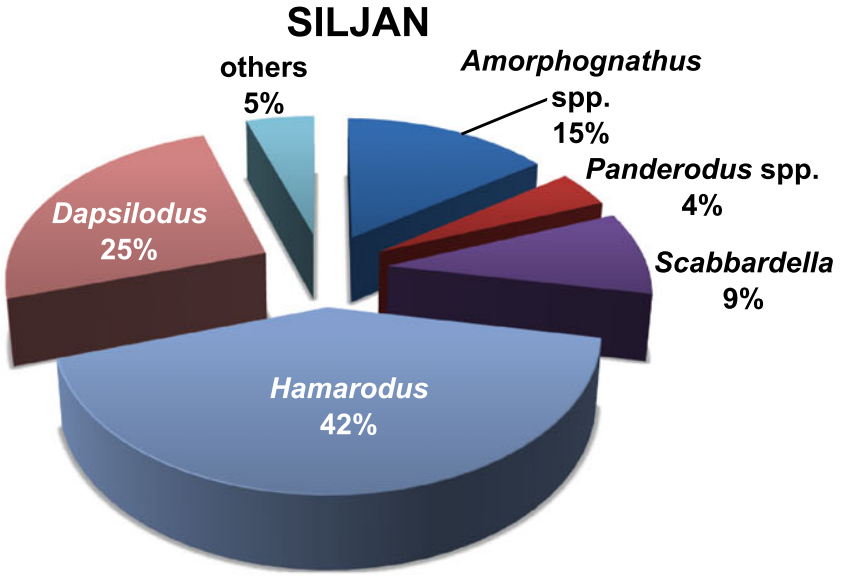

E

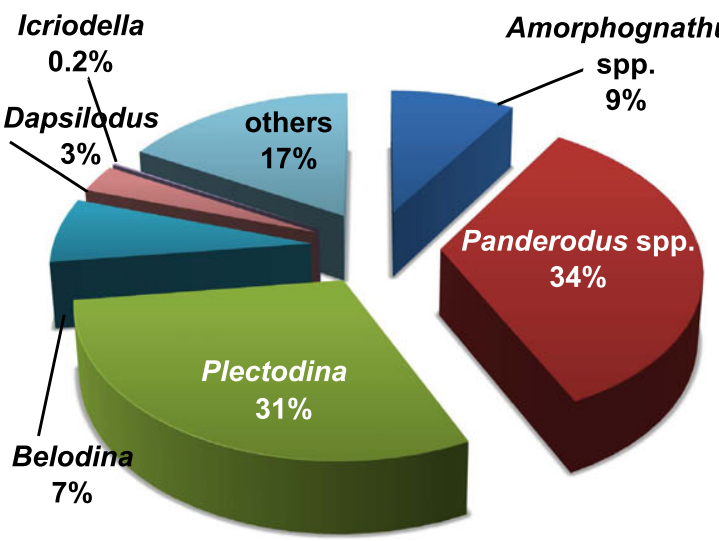

D THURINGIA

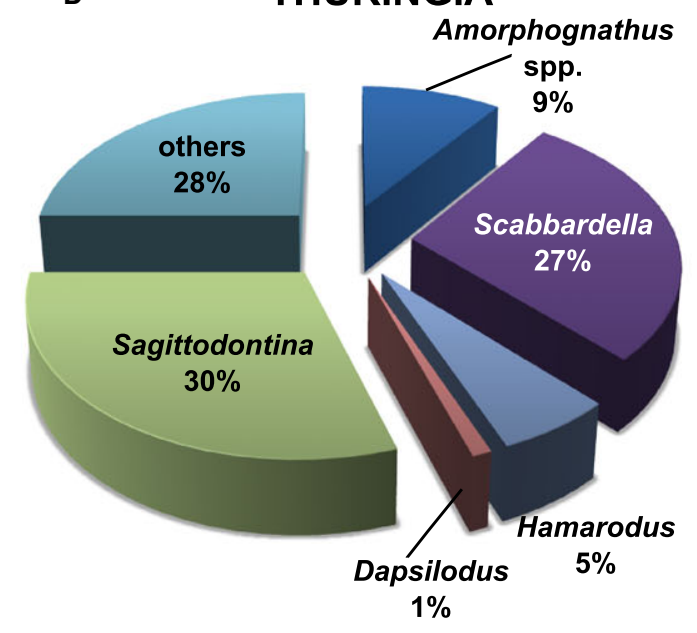

$\mathbf{F}$

CRÛG

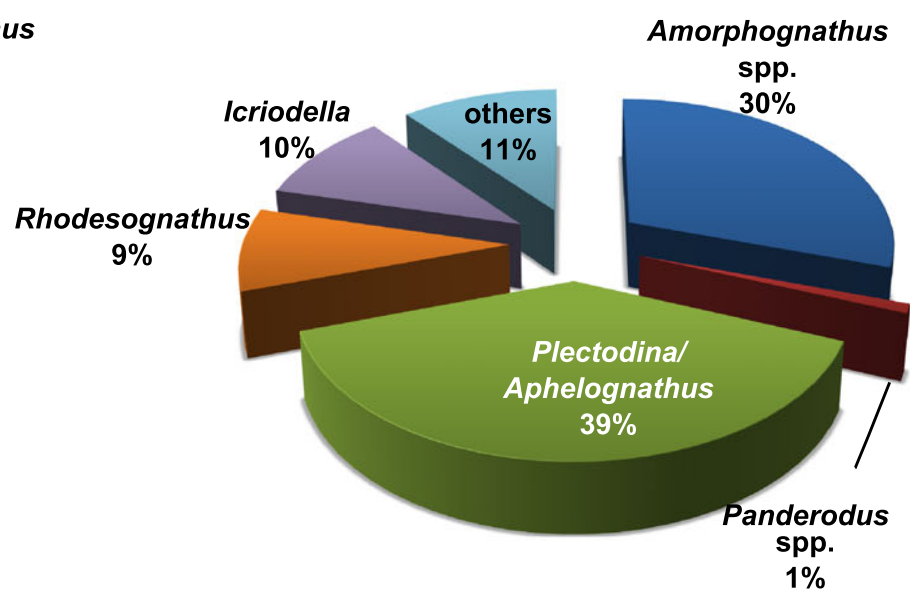


not differ much in age although part of the Crûg Limestone may be slightly older than the latter unit (cf. Fig. 9).

\section{Birdshill Limestone}

The type locality of this unit is an abandoned quarry just west-north-west of Birdshill Farm west of Llandeilo, Carmarthenshire. For locality information, see Strahan et al. (1907) and Bergström (1964). In view of the fact that this locality is only about $3 \mathrm{~km}$ from the Crûg Limestone outcrop and these units have yielded similar macrofossil faunas, it is not surprising that also the conodont faunas show a great deal of similarity. Conodonts from this unit were first recorded by Bergström (1964), and later records include Orchard (1980) and Savage and Bassett (1985).

The conodont faunas as now known (cf. Orchard 1980 and Savage and Bassett 1985) are characterized by the presence of species of Amorphognathus along with Icriodella superba, Ozarkodina pseudofissilis, Baltoniodus aff. B. alobatus, Rhodesognathus elegans, Eocarniodus sp., Protopanderodus cf. P. liripipus, Pseudooneotodus mitratus and Scabbardella cf. S. altipes. Although the state of preservation is not as good as in the case of the conodonts from the Crûg Limestone, the Birdshill Limestone conodont fauna is virtually identical to that of the former unit, the only possible difference being the apparent absence of Aphelognathus rhodesi. Whereas Bergström (1971a), Orchard (1980) and Bergström and Orchard (1985) referred the Birdshill Limestone to the A. superbus Zone, Savage and Bassett (1985) classified it with the A. ordovicicus Zone based on $\mathrm{Pb}$ elements of Amorphognathus. However, the latter authors recovered no $\mathrm{M}$ elements (cf. their table 1) from this formation, and the Birdshill $\mathrm{M}$ element illustrated by Orchard (1980, pl. 44, fig. 24) is referable to A. superbus and quite unlike that in A. ordovicicus. Both the Birdshill and Crûg limestones appear to represent an interval near the base of the A. ordovicicus Zone, and based on conodonts, it is difficult to determine whether they are slightly older than the Sholeshook Limestone at Whitland.
Other conodont faunas from Wales and the Welsh Borderland

Because the Caradocian conodont faunas from the Bala district in north-central Wales and the Welsh Borderland (Rhodes 1953; Bergström 1964, 1971a; Savage and Bassett 1985) are from the A. tvaerensis and A. superbus zones and hence are clearly older than those of the Sholeshook Limestone, they are not used herein for comparison. Furthermore, the systematic classification of some of the taxa described from these units is in need of revision, and such a revision is outside the scope of the present study.

\section{Northern England}

The regional Ashgill Series has its type area in northern England where it is subdivided into the Pusgillian, Cautleyan, Rawtheyan and Hirnantian stages (Fig. 1). Ingham (1966) recognized eight numbered shelly fossil zones in the Ashgill Series, four of which (Zones 1-4) are in the Cautleyan Stage. Since its original introduction, the correlation of the Cautleyan Stage has undergone a significant revision based on studies of conodonts (Orchard 1980) and chitinozoans (Vandenbroucke et al. 2005).

Among the conodont faunas described from this region by Orchard (1980), those from the Cautleyan Zone 2, and possibly Zone 3, of the Murthwaite and Taythes Gill inliers should be equivalent to that of the Sholeshook Limestone. Unfortunately, the lithology of most of the Cautleyan Stage in its type region is not favourable for extracting conodonts, as shown by the yield reported by Orchard (1980, fig. 1) that ranged from 1.5 to 6.8 specimens $/ \mathrm{kg}$ of dissolved rocks. Hence, it can be expected that the collections recovered with much effort by Orchard (1980), which include less than 500 specimens, do not contain all the conodont species present in that study interval, the less common species having not been recovered.

The Zone 2 fauna is dominated by representatives of Amorphognathus (c. 44\%), Panderodus spp. (c. 30\%) and Plectodina/Aphelognathus (c. 6\%), whereas elements of Belodina, Birksfeldia, Belodella, Icriodella, Scabbardella, Walliserodus and a few other taxa are much less common

FIG. 8. Pie diagrams illustrating provincial differences in relative abundance of conodont genera in the lower Amorphognathus ordovicicus Zone of regions discussed in the text. A, Sholeshook Limestone, South Wales, British Province (data presented herein). B, Lower Cautley Mudstone, northern England, British Province (based on Orchard 1980). C, Upper Slandrom Limestone, Siljan Region, Sweden, Baltic Province (SMB coll.). D, Kalkbank, Thuringia, Germany, Mediterranean Province (based on Ferretti and Barnes 1997). E, Upper Dubuque Formation, Iowa, USA, Red River Province (SMB coll.). For comparison, in F, we include data from the presumed upper Amorphognathus superbus Zone of the Crûg Limestone, South Wales, British Province (mainly after Savage and Bassett 1985). For discussion of the various provincial differences, see the text. As is the case with other faunas discussed below, the frequency percentages of the taxa in the collections are based on the number of specimens identified to species, or only genus, and no attention has been given to indeterminable specimens. 


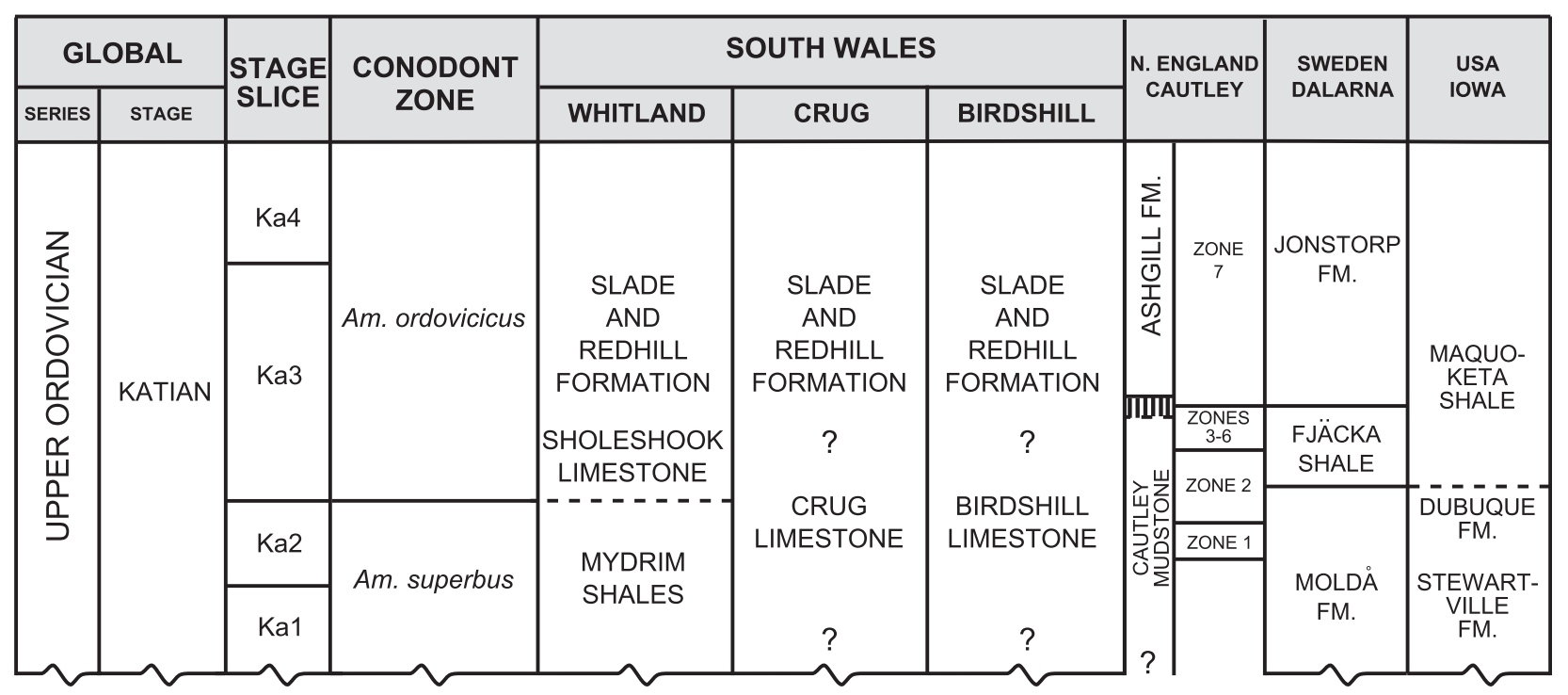

FIG. 9. Correlation diagram showing the inferred relationships between the Sholeshook Limestone and British, Baltoscandic and North American units discussed in the text.

(in most cases <2\%; Fig. 8). Specimens of Baltoniodus and Rhodesognathus, which are well represented in the Welsh A. superbus Zone, have not yet been recorded in the Cautleyan Stage in northern England. The apparent absence of the long-ranging Drepanoistodus suberectus, Phragmodus undatus and Protopanderodus liripipus is likely due to collecting failure. As noted by Orchard (1980, fig. 3), there is a notable turnover in the conodont fauna in Cautleyan Zone 2, but the significance of this remains unclear. Interestingly, Vandenbroucke et al. (2005) recognized a broadly coeval turnover in the chitinozoan fauna and noted that judging from the rock record, it was not associated with a significant environmental change.

The conodont fauna of the lower A. ordovicicus Zone in Zones 2 and 3 of the Cautleyan Stage compares well with that of the Sholeshook Limestone. Virtually, all of the Zone 2 species (Table 1) are present in the latter formation. As noted by Orchard (1980, fig. 1), the distinctive genera Plectodina and Aphelognathus, which are well represented in particularly in the Crûg Limestone but also occur in the Sholeshook Limestone, range through the regional Pusgillian Stage and into the lower Cautleyan Stage in northern England. Orchard (1980, pl. 4, figs 23, 26) recovered several $M$ elements of Amorphognathus, which he referred to A. cf. A. superbus, from the Cautleyan Zone 2. Although no $M$ element typical of $A$. ordovicicus was found, the presence of these elements, which are transitional to those of $A$. ordovicicus, was taken as an indication that the base of the A. ordovicicus Zone corresponds to a level in Zone 2. As far as can be seen in the illustrations of these rather poorly preserved specimens, they are similar to M elements of Amorphognathus pres- ent in the uppermost A. superbus Zone of the Collingwood Member of the Lindsay Formation of southern Ontario (Zhang et al. 2011). We conclude that based on conodonts, the Sholeshook Limestone is coeval with the Cautleyan Zone 2 and hence is of early-middle Ashgillian in age in terms of the British regional series classification.

Interestingly, in a detailed chitinozoan study of the Cautleyan Stage, Vandenbroucke et al. (2005, fig. 11) classified its Zone 2 as being located between the Fungochitina spinifera and Tanuchitina bergstroemi zones. This is in excellent agreement with the relationships between conodont and chitinozoan zones in Baltoscandia, where the base of the A. ordovicicus Zone is in the uppermost Slandrom Limestone (Bergström 1971a). As shown in Fig. 1, this unit represents the uppermost F. spinifera Zone (Grahn and Nõlvak 2010). As noted above, in terms of graptolite biostratigraphy, the Slandrom Limestone is correlated with the lower Pleurograptus linearis Zone, and while Rickards (2002) recorded graptolites of the P. linearis Zone from Ashgill Zones 5 and 6, no diagnostic graptolites have yet been found in Zone 2. However, both chitinozoans and conodonts suggest that Zone 2 corresponds to the lower P. linearis Zone. This is consistent with the fact that according to Rickards (2002), the Cautleyan Stage corresponds to part of the P. linearis Zone.

\section{INTERNATIONAL COMPARISONS}

\section{Baltoscandia}

Middle Katian (lower A. ordovicicus Zone) conodonts are known from a significant number of localities in Estonia, 
TABLE 1. Occurrences of conodont taxa identified in the collections from Sholeshook Limestone (this study); Cautleyan Zone 2, northern England (Orchard 1980); uppermost Slandrom Limestone, Siljan Region, Sweden (SMB coll.); Kalkbank, Thuringia (Ferretti and Barnes 1997); upper Dubuque Formation, Iowa (SMB coll.). Note differences in faunal composition between the British, Baltoscandic, Mediterranean and Red River provinces.

\begin{tabular}{|c|c|c|c|c|}
\hline Sholeshook Limestone & Cautley Ms. & Slandrom Ls. & Kalkbank & Dubuque Fm. \\
\hline Amorphognathus duftonus Rhodes, 1955 & - & - & - & - \\
\hline Amorphognathus ordovicicus Branson and Mehl, 1933 & $\times$ & $\times$ & $\times$ & $x$ \\
\hline Amorphognathus superbus (Rhodes, 1953) & $x$ & - & - & - \\
\hline Amorphognathus ventilatus Ferretti and Barnes, 1997 & $x$ & - & $x$ & - \\
\hline Aphelognathus rhodesi Lindström, 1959 & - & - & - & - \\
\hline Belodina cf. B. confluens Sweet, $1979 b$ & $x$ & - & - & $x$ \\
\hline Birksfeldia circumplicata Orchard, 1980 & $x$ & $x$ & - & - \\
\hline Cornuodus sp. & - & - & $\times$ & - \\
\hline Dapsilodus mutatus (Branson and Mehl, 1933) & $\times$ & $\times$ & $\times$ & $\times$ \\
\hline Decoriconus costulatus (Rexroad, 1967) & - & - & - & - \\
\hline Drepanoistodus suberectus (Branson and Mehl, 1933) & $x$ & $x$ & $?$ & $\times$ \\
\hline Eocarniodus aff. E. gracilis (Rhodes, 1955) & - & - & - & - \\
\hline Hamarodus brevirameus (Walliser, 1964) & $\times$ & $\times$ & $x$ & - \\
\hline Icriodella superba Rhodes, 1953 & $?$ & $?$ & $?$ & $\times$ \\
\hline Istorinus sp. & - & - & $x$ & - \\
\hline Ozarkodina pseudofissilis (Lindström, 1959) & $x$ & - & - & - \\
\hline Panderodus gracilis (Branson and Mehl, 1933) & $\times$ & $x$ & cf. & - \\
\hline Panderodus serratus Rexroad, 1967 & - & - & - & - \\
\hline Phragmodus undatus Branson and Mehl, 1933 & - & - & - & $\times$ \\
\hline Plectodina sp. & $\times$ & - & - & - \\
\hline Protopanderodus liripipus Kennedy, Barnes and Uyeno, 1979 & cf. & $x$ & - & $x$ \\
\hline Pseudooneotodus spp. & $x$ & - & - & - \\
\hline Rhodesognathus elegans (Rhodes, 1953) & - & - & - & $x$ \\
\hline Sagittodontina sp. & - & - & $x$ & - \\
\hline Scabbardella altipes (Henningsmoen, 1948) & $\times$ & $x$ & $\times$ & - \\
\hline Staufferella cf. S. inaligera McCracken and Barnes, 1981 & $x$ & $x$ & $x$ & - \\
\hline Venoistodus venustus (Stauffer, 1935) & $\times$ & $x$ & - & $x$ \\
\hline Walliserodus amplissimus (Serpagli, 1967) & - & - & - & - \\
\hline
\end{tabular}

Latvia and Scandinavia (Bergström 1971a, 2007; Bergström et al. 2011b; Männik and Viira 2012), and the conodont species succession in this interval is now documented in great detail.

The East Baltic and Swedish conodont faunas in the lower A. ordovicicus Zone are virtually identical (Bergström 2007; Männik and Viira 2012) and include a little more than 20 multielement species. Four samples containing a total of almost 2000 specimens from the lowermost A. ordovicicus Zone in the Slandrom Limestone at Skallberget in the Siljan region of south-central Sweden (SMB coll.; cf. Table 2) were used for species percentages. Apart from a few taxonomically more or less unclear coniform species, the fauna is characterized by, among others, A. ordovicicus (c. 15\%), Dapsilodus mutatus (c. 25\%), Hamarodus brevirameus (c. 42\%), Scabbardella altipes (c. 9\%) and Panderodus spp. (c. 4\%). Rare taxa present in other samples, which are usually known only in single specimens, include Periodon grandis, Birksfeldia sp., Belodina confluens, Icriodella sp., Plectodina tenuis, Protopand- erodus liripipus, Strachanognathus parvus and Pseudobelodina dispansa. No specimens of Aphelognathus, Baltoniodus, Belodella, Eocarniodus and Phragmodus have been recorded in the Skallberget samples, but Phragmodus undatus occurs as rare specimens elsewhere in the upper Katian of Sweden (Bergström 2007).

These Baltoscandic conodont faunas exhibit considerable similarity to that of the Sholeshook Limestone in having about 10 taxa in common (Fig. 8). Major differences include the apparent absence in the Baltoscandic faunas of Aphelognathus, Eocarniodus, Istorinus, Ozarkodina, Sagittodontina and Staufferella. Among these taxa, Aphelognathus, Ozarkodina, Phragmodus and Staufferella have North American provincial affinities, whereas Sagittodontina is best known from the Mediterranean Province (Sweet and Bergström 1984). Hence, although seemingly lacking endemic species, the Baltoscandic faunas of this age have their own provincial character and include relatively few possible immigrants from other areas. Based on this, Sweet and Bergström (1984) recognized a separate 
TABLE 2. Frequency of conodont taxa in samples from the upper Slandrom Limestone at the Skålberget North section, Siljan area, Province of Dalarna, south-central Sweden.

\begin{tabular}{|c|c|c|}
\hline Conodont species & $\begin{array}{l}\text { No. of } \\
\text { specimens }\end{array}$ & $\begin{array}{l}\text { Percentage of } \\
\text { collection }\end{array}$ \\
\hline $\begin{array}{l}\text { Amorphognathus ordovicicus Branson } \\
\text { and Mehl, } 1933\end{array}$ & 300 & 15.3 \\
\hline Birksfeldia sp. & 2 & 0.1 \\
\hline $\begin{array}{l}\text { Dapsilodus mutatus (Branson and } \\
\text { Mehl, 1933) }\end{array}$ & 495 & 25.2 \\
\hline $\begin{array}{l}\text { Decoriconus costulatus (Rexroad, } \\
\text { 1967) }\end{array}$ & 38 & 1.9 \\
\hline $\begin{array}{l}\text { Drepanoistodus suberectus (Branson } \\
\text { and Mehl, 1933) }\end{array}$ & 28 & 1.4 \\
\hline $\begin{array}{l}\text { Hamarodus brevirameus (Walliser, } \\
\text { 1964) }\end{array}$ & 826 & 42.1 \\
\hline Icriodella sp. & 1 & 0.05 \\
\hline Panderodus spp. & 75 & 3.8 \\
\hline $\begin{array}{l}\text { Protopanderodus liripipus Kennedy, } \\
\text { Barnes and Uyeno, } 1979\end{array}$ & 24 & 1.2 \\
\hline Pseudooneotodus spp. & 1 & 0.05 \\
\hline $\begin{array}{l}\text { Scabbardella altipes (Henningsmoen, } \\
\text { 1948) }\end{array}$ & 172 & 8.8 \\
\hline Venoistodus venustus (Stauffer, 1935) & 1 & 0.05 \\
\hline Total & 1963 & \\
\hline
\end{tabular}

Baltoscandic Province. However, this type of conodont fauna has an obvious general similarity to the coeval faunas from the British Province.

\section{Thuringia, Germany}

A thin (0.1- to 0.4-m-thick) limestone bed, known as the Kalkbank, in the Schmiedefeld Formation in the otherwise clastic Upper Ordovician succession in south-eastern Germany has yielded a conodont fauna of abundant specimens but of low species diversity (Knüpfer 1967; Sweet and Bergström 1984; Fuchs 1989, 1990; Ferretti and Barnes 1997). Ferretti and Barnes (1997) recognized in this fauna nine taxa identified to species and four additional ones referred only to genus. Dominant taxa are Sagittodontina robusta (c. 30\%), Scabbardella altipes (c. 27\%) and Istorinus erectus (c. 20\%; Fig. 8). Other common taxa include species of Amorphognathus (c. 9\%) and Hamarodus brevirameus (c. 5\%), whereas specimens of Cornuodus, Dapsilodus mutatus, Drepanoistodus, Icriodella and Panderodus are far less frequent (all <4\%).

Based on the presence of Amorphognathus ordovicicus, the Kalkbank fauna is clearly not older than the A. ordovicicus Zone and it seems likely that it is at least broadly coeval with that of the Sholeshook Limestone. This is consistent with the fact that species of Amorphognathus, as well as Dapsilodus mutatus, Hamarodus brevirameus,
Istorinus and Scabbardella altipes, are shared with the Sholeshook Limestone fauna. Although the Kalkbank fauna also contains very rare specimens of Icriodella and Walliserodus, the general aspect of this fauna with its dominant occurrence of Sagittodontina robusta and Scabbardella altipes differs conspicuously from that of the Sholeshook Limestone and coeval British faunas as well as coeval ones from Baltoscandia. The Kalkbank fauna is typical of the Mediterranean Province (Sweet and Bergström 1984; Ferretti and Barnes 1997) and is similar to conodont faunas recorded from Spain (Fuganti and Serpagli 1968; Sarmiento 1990; Ferretti 1992; Del Moral and Sarmiento 2008), France (Weyant et al. 1977), Sardinia (Ferretti and Serpagli 1991) and Libya (Bergström and Massa 1992). Based on the distinctive appearance of this type of fauna, Sweet and Bergström (1984) referred the Kalkbank fauna to a separate biofacies, the Sagittodontina robusta-Scabbardella altipes biofacies, whereas the broadly equivalent Baltoscandic faunas were referred to the $\mathrm{Ha}$ marodus europaeus (now brevirameus) - Dapsilodus mutatus - Scabbardella altipes biofacies. Middle to upper Katian British faunas from Wales and England, which now include the Sholeshook Limestone fauna, were referred to a third biofacies, the Amorphognathus-Plectodina biofacies. New data obtained from investigations in Europe during the last 30 years have supported the existence of this differentiation into three major biofacies in much of the Upper Ordovician. Whereas the Mediterranean Province faunas apparently occupied high latitude, relatively cold waters near the pole, those of the British and Baltic provinces inhabited marine environments at lower latitudes.

\section{North American Midcontinent}

Very well-preserved conodonts from the lower A. ordovicicus Zone have been described from several regions in North America, which occupied an equatorial position during the Late Ordovician. These include West Texas (Bergström 1978) and the adjacent part of New Mexico (Sweet 1979b), Iowa and Minnesota (Ethington 1959; Webers 1966; Goldman and Bergström 1997), the Cincinnati region of Ohio and adjacent states (Kohut and Sweet 1968; Sweet 1979a; Bergström and MacKenzie 2005), the Arbuckle Mountains of Oklahoma (Dresbach 1983; Sweet 1983; Goldman and Bergström 1997), the Great Basin of Nevada (Sweet 1979b) and the Bruce Peninsula - Manitoulin Island region of southern Ontario (Zhang et al. 2011).

Among the conodont faunas listed above, we use for comparison with the Sholeshook Limestone the diverse fauna from the upper Dubuque Formation of Iowa. The upper part of this unit, as well as the unconformably 
overlying Maquoketa Formation, represents the lowermost Amorphognathus ordovicicus Zone (Ethington 1959; Webers 1966) as shown by the presence in the upper Dubuque Formation of Amorphognathus ordovicicus M elements described as Goniodontus superbus by Ethington (1959) and reported also from the Maquoketa Formation by Glenister (1957, pl. 88, fig. 25) and Webers (1966, pl. 13, fig. 12). A similar $M$ element from the Dubuque Formation was illustrated and identified as A. ordovicicus by Bergström and Leslie (2010, fig. 5).

No graptolites are known from the Dubuque Formation, but Goldman and Bergström (1997) recorded graptolites of the Amplexograptus manitoulinensis Zone (stage slice Ka3) from the lower part of the overlying Maquoketa Shale and Dicellograptus complanatus, the index of the base of stage slice Ka4, from the middle part of the Maquoketa Shale. Hence, the evidence of the age of the upper Dubuque Formation from these fossils groups is in excellent agreement.

As shown by a collection of about 7000 specimens from nine very productive samples (SMB coll.; cf. Table 3) from the uppermost Dubuque Formation exposed in a road cut along Highway 9 about $10 \mathrm{~km}$ east of Decorah, Iowa, the conodont fauna from this interval includes approximately 20 multielement species. By far, most common are species of Panderodus (c. 35\%), Plecto-

TABLE 3. Frequency of conodont taxa in samples from the upper Dubuque Formation at the road cut section along Highway 9 about $10 \mathrm{~km}$ ESE of Decorah, Iowa.

\begin{tabular}{|c|c|c|}
\hline Conodont species & $\begin{array}{l}\text { No. of } \\
\text { specimens }\end{array}$ & $\begin{array}{l}\text { Percentage of } \\
\text { collection }\end{array}$ \\
\hline Amorphognathus spp. & 621 & 9 \\
\hline Belodina confluens Sweet, $1979 b$ & 431 & 6.3 \\
\hline Belodina dispansa Glenister, 1957 & 74 & 1.1 \\
\hline Columbodina penna Sweet, 1979b & 15 & 0.2 \\
\hline $\begin{array}{l}\text { Coelocerodontus trigonius Ethington, } \\
1959\end{array}$ & 8 & 0.1 \\
\hline $\begin{array}{l}\text { Dapsilodus mutatus (Branson and } \\
\text { Mehl, 1933) }\end{array}$ & 228 & 3.3 \\
\hline $\begin{array}{l}\text { Drepanoistodus suberectus (Branson } \\
\text { and Mehl, 1933) }\end{array}$ & 631 & 9.2 \\
\hline Icriodella superba Rhodes, 1953 & 13 & 0.2 \\
\hline Panderodus spp. & 2370 & 34.5 \\
\hline Periodon grandis (Ethington, 1959) & 74 & 1.1 \\
\hline $\begin{array}{l}\text { Phragmodus undatus Branson and } \\
\text { Mehl, } 1933\end{array}$ & 4 & 0.05 \\
\hline $\begin{array}{l}\text { Plectodina tenuis (Branson \& Mehl, } \\
\text { 1933) }\end{array}$ & 2109 & 30.7 \\
\hline $\begin{array}{l}\text { Protopanderodus liripipus Kennedy, } \\
\text { Barnes and Uyeno, } 1979\end{array}$ & 169 & 2.5 \\
\hline Staufferella falcata (Stauffer, 1935) & 19 & 0.3 \\
\hline Venoistodus venustus (Stauffer, 1935) & 108 & 1.6 \\
\hline Total & 6874 & \\
\hline
\end{tabular}

dina tenuis (c. 31\%), Drepanoistodus suberectus (c. 9\%), Amorphognathus ordovicicus (c. 9\%) and Belodina confluens (c. 6\%; Fig. 8). The other species present occur in abundances of less than 5 per cent. A number of otherwise widespread and locally common species of Columbodina, Icriodella, Periodon, Phragmodus and Rhodesognathus occur in frequencies of 1 per cent or less, and widely distributed taxa of Aphelognathus, Hamarodus, Oulodus and Scabbardella are not at all represented. Hence, although apparently being of the same age, the Dubuque fauna is strikingly different from that of the Sholeshook Limestone.

In their global review of the Katian provincial differentiation of conodont faunas, Sweet and Bergström (1984) recognized in the North American Midcontinent an Ohio River Province and a Red River Province, but they did not discuss any collections from Minnesota and Iowa. However, the Dubuque fauna is virtually identical to that of the Cape Limestone of Missouri (Sweet et al. 1975), which was referred to the Red River Province in their statistical assessment. Hence, the Dubuque fauna is herein considered to represent the Red River Province.

\section{Summary of international stage correlation}

The stratigraphic relationships of the Sholeshook Limestone at Whitland are summarized in Figure 9. The conodont faunas of the lower Amorphognathus ordovicicus Zone of the Sholeshook Limestone and those of this zone interval at other localities in Wales, North England, Baltoscandia and North America provide a very useful tool for new and detailed long-distance correlations that differ significantly from those presented in British standard summaries such as that by Fortey et al. (2000, fig. 34). As shown in Fig. 1, using the conodont evidence at hand, we conclude that the British lower Cautleyan Stage (especially Zone 2) corresponds to an interval in the North American lower Richmondian Stage and the Baltoscandian Nabala Stage. Because of the conspicuous faunal provincialism in the Upper Ordovician, the previously uncertain relationships between this important interval in these regional stages have now been clarified. It should also be noted that the proposed correlations are consistent with currently available, but less conclusive, evidence from graptolites and chitinozoans.

\section{COMMENTS ON THE AMORPHOGNATHUS LINEAGE}

Representatives of Amorphognathus Branson and Mehl, 1933 are abundant in the Whitland fauna, and because this genus is of particular phylogenetic and biostrati- 
graphical interest, it is appropriate to briefly review the Amorphognathus evolutionary lineage with special regard to the morphology and current classification of the Katian species. For a recent general summary see Bergström and Leslie (2010).

Important diagnostic features used for Amorphognathus include the appearance of the platform in the Pa elements and the number and distribution of denticles on the upper edge of the $\mathrm{M}$ element. The $\mathrm{Pb}$ and $\mathrm{S}$ elements are quite similar in most species and are currently of little use in the taxonomy. A conspicuous evolutionary trend seen in the $\mathrm{M}$ element is the increase in cusp size, decrease in number and size of adjacent apical denticles and the decrease in the length of the processes (Bergström 1971a, 1983; Orchard 1980; Dzik 1984, 1999; Bergström and Leslie 2010). In erecting the new species Amorphognathus ventilatus from the Upper Ordovician Kalkbank of Thuringia, Ferretti and Barnes (1997, p. 20) summarized these trends as 'the evolution of the $\mathrm{M}$ element in the Amorphognathus lineage, starting from the older A. tvaerensis, shows a gradual reduction in number, and final disappearance, of the denticle on the inner anterior process, a contraction of the anterior aboral process, which eventually disappears in A. ordovicicus, the development of a prominent and discrete cusp, a reduction in the inclination and an increase in cusp size'.

Amorphognathus ordovicicus Branson and Mehl, 1933, the type species of Amorphognathus, and the index of the A. ordovicicus Zone, was originally based on unpaired platform elements occupying the Pa position in the apparatus. Walliser (1964), Bergström and Sweet (1966) and Webers (1966) recognized that these platform elements were consistently associated with another type of element, which was described as Ambalodus triangularis by Branson and Mehl (1933), and this element was included in the apparatus when the species was classified in multielement taxonomy (Bergström and Sweet 1966). Later, Bergström (1971a) reconstructed a more complex Amorphognathus apparatus by adding several types of ramiform $\mathrm{S}$ elements as well as an M element, which previously had been referred to the genus Holodontus Rhodes, 1953. This association of elements has been confirmed by subsequent studies of many conodont faunas and also by the discovery of an Amorphognathus black shale bedding plane assemblage (DG and SMB unpubl. data). As indicated by Bergström (1983, fig. 13), the fact that the Amorphognathus apparatus is reminiscent of that of Lenodus Sergeeva, 1963 and Baltoniodus Lindström, 1971 suggests that Amorphognathus might have evolved from one of these genera, possibly in Dapingian time (Bergström and Leslie 2010), but truly transitional taxa are not yet known.

The two stratigraphically oldest species currently recognized in the Amorphognathus lineage are the Sandbian A. inaequalis Rhodes, 1953 and A. tvaerensis Bergström,
1962 (cf. Bergström 1983). The stratigraphically next youngest species is A. superbus, the index of the A. superbus Zone. This species is likely to have evolved from A. tvaerensis in early, but not earliest, Katian (stage slice Ka1) time. Occurring in strata of approximately the same age as those having A. superbus is the distinctive species A. complicatus Rhodes, 1953, which has a wide distribution in northern Europe and China. As indicated by Bergström and Leslie (2010), the presence of specimens that are intermediate between A. superbus and A. complicatus in the Pagoda Limestone of China (An 1987, fig. 30:12) indicates that A. complicatus evolved from A. superbus. This species was first described from the Bala area in North Wales (Rhodes 1953), but it has not yet been found at Whitland. It typically occurs in slightly older strata than the Sholeshook Limestone.

Among the numerous specimens of Amorphognathus in the Whitland collections, many belong to A. ordovicicus, which provides basis for referring the Sholeshook Limestone to the A. ordovicicus Zone. Of special importance is the recovery of more than $500 \mathrm{M}$ (holodontiform) elements of Amorphognathus in our samples from the Sholeshook Limestone. Such elements have been used to discriminate between several species of Amorphognathus, but this type of element is generally sparse in most other faunas and our collection is likely to be largest one assembled anywhere in the world.

As shown especially well in our Sholeshook Limestone collection, there was a major speciation event in the Amorphognathus lineage in the lower A. ordovicicus Zone. This event is not very clearly expressed in the morphology of the $\mathrm{Pa}, \mathrm{Pb}$ and $\mathrm{S}$ elements and is mainly shown in the variety of shapes of the $\mathrm{M}$ element (Fig. 7). Whether or not these different shape groups of the $\mathrm{M}$ element reflect true biological species is of course a matter of speculation, especially as it is biologically suspect that several very closely related forms seem to have been coexisting in the same environment. Yet, some of these $M$ forms appear to have become stabilized morphologically as morphospecies as shown by the fact that they have significant stratigraphic ranges in the upper Katian and locally, such specific forms may dominate the Amorphognathus M element populations. Examples of this are the dominance of A. ventilatus in the Kalkbank of Thuringia (Ferretti and Barnes 1997) and A. duftonus (senior synonym of A. lindstroemi) in the Keisley Limestone of northern England (SMB and AF, in prep.). Some of the taxa with other types of $\mathrm{M}$ elements appear to have been stratigraphically short-lived and may be interpreted as having been evolutionary dead end mutations. Each of the more important taxa is discussed below.

In the Whitland section, $\mathrm{M}$ elements assigned to A. ordovicicus (Fig. 7O) occur from the base of the Sholeshook Limestone with evolutionarily early forms 
TABLE 4. Review of major morphological characteristics of the M element of selected species of Amorphognathus and Rhodesognathus.

\begin{tabular}{|c|c|c|c|c|c|c|}
\hline & $\begin{array}{l}\text { Anterior } \\
\text { inner } \\
\text { process }\end{array}$ & $\begin{array}{l}\text { Anterior } \\
\text { outer } \\
\text { process }\end{array}$ & $\begin{array}{l}\text { Posterior } \\
\text { process }\end{array}$ & $\begin{array}{l}\text { Denticle/s } \\
\text { anterior to } \\
\text { the cusp }\end{array}$ & $\begin{array}{l}\text { Denticle/s } \\
\text { posterior } \\
\text { to the cusp }\end{array}$ & $\begin{array}{l}\text { Orientation } \\
\text { of the cusp }\end{array}$ \\
\hline Amorphognathus duftonus Rhodes, 1955 & Absent & Present & Present & Absent & Present (one) & Erect \\
\hline Amorphognathus ordovicicus Branson and Mehl, 1933 & Absent & Present & Present & Absent & Absent & Erect \\
\hline Amorphognathus superbus (Rhodes, 1953) & Present & Present & Present & Present & Present & Erect \\
\hline Amorphognathus ventilatus Ferretti and Barnes, 1997 & Present & Present & Present & Absent & Present & Erect \\
\hline Holodontiform element A & Present & Present & Present & Present & Absent & Erect \\
\hline Rhodesognathus elegans (Rhodes, 1953) & Present & Present & Present & Present & Present & Reclined \\
\hline
\end{tabular}

being present in the lowermost samples. A. duftonus (Fig. 7D) is present through the entire succession, and as described in the Systematic Palaeontology section of this paper, there is an evolutionary trend expressed in the morphology of its $M$ element through its Sholeshook Limestone range. In the lower $1 / 3$ of the Sholeshook Limestone, A. superbus (Fig. 7S) is present in low numbers together with early representatives of $A$. ordovicicus. A. ventilatus occurs in moderately large numbers through the whole Whitland succession and is especially common in the upper $2 / 3$ of the unit. It shows little morphological variation. The $\mathrm{M}$ elements possess a definite inner-lateral process with denticles developed on the outer-lateral flank of the cusp (Fig. 7V).

The $\mathrm{M}$ elements assigned to A. ventilatus clearly have a long anterior inner process, which is absent in the corresponding element in A. ordovicicus. Also, the $\mathrm{M}$ element cusp in the latter species is wider and shorter. For these reasons, we regard $A$. ordovicicus and $A$. ventilatus as separate but closely related species. The presence of these two species in the Whitland collections confirms that A. ventilatus occurs in the A. ordovicicus Zone also outside Germany. The presence of several species of Amorphognathus in the lower part of the Sholeshook Limestone suggests that this interval was a hot bed in terms of the evolution of this genus. Some types of the diagnostic M element are illustrated in Figure 7, and the principal char- acteristics of this element in some species of Amorphognathus and Rhodesognathus discussed above are summarized in Table 4.

\section{SYSTEMATIC PALAEONTOLOGY}

Repository. The conodont collections are deposited in the 'Inventario Paleontologia Università di Modena e Reggio Emilia' at the Dipartimento di Scienze Chimiche e Geologiche, Modena, Italy, under repository numbers IPUM 28331-28461.

Remarks. Most of the species present in the Whitland collections are well-known taxa that have been described adequately in the literature. Accordingly, there is no need to redescribe these species, but most of these are drawn in Figures 7 and 10 or illustrated in Figures 11-17. A few important Whitland taxa are formally dealt with below. Note that in the synonymy lists, only key synonyms are given. The guidelines provided by Matthews (1973) were followed in the synonymy list.

Genus AMORPHOGNATHUS Branson and Mehl, 1933

Type species. Amorphognathus ordovicicus Branson and Mehl, 1933; Upper Ordovician (upper Katian); Missouri, USA (cf. Bergström and Leslie 2010).
FIG. 10. Some types of conodont elements referred to Eocarniodus aff. E. gracilis (Rhodes, 1955). Scale bars represent $100 \mu \mathrm{m}$.

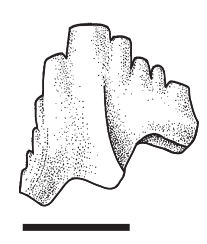

?P

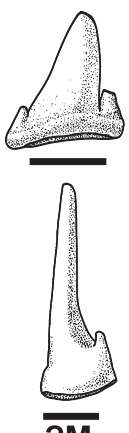

?M

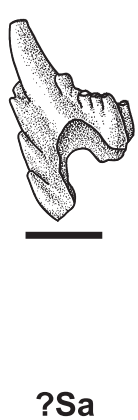

?Sa
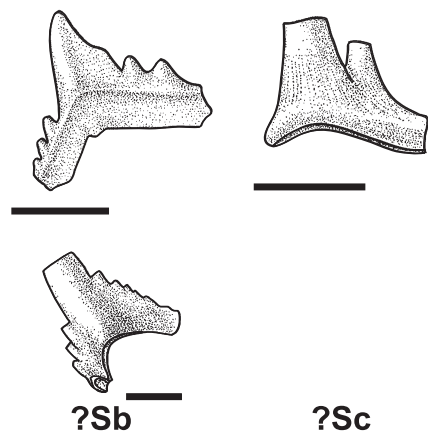

?Sc 


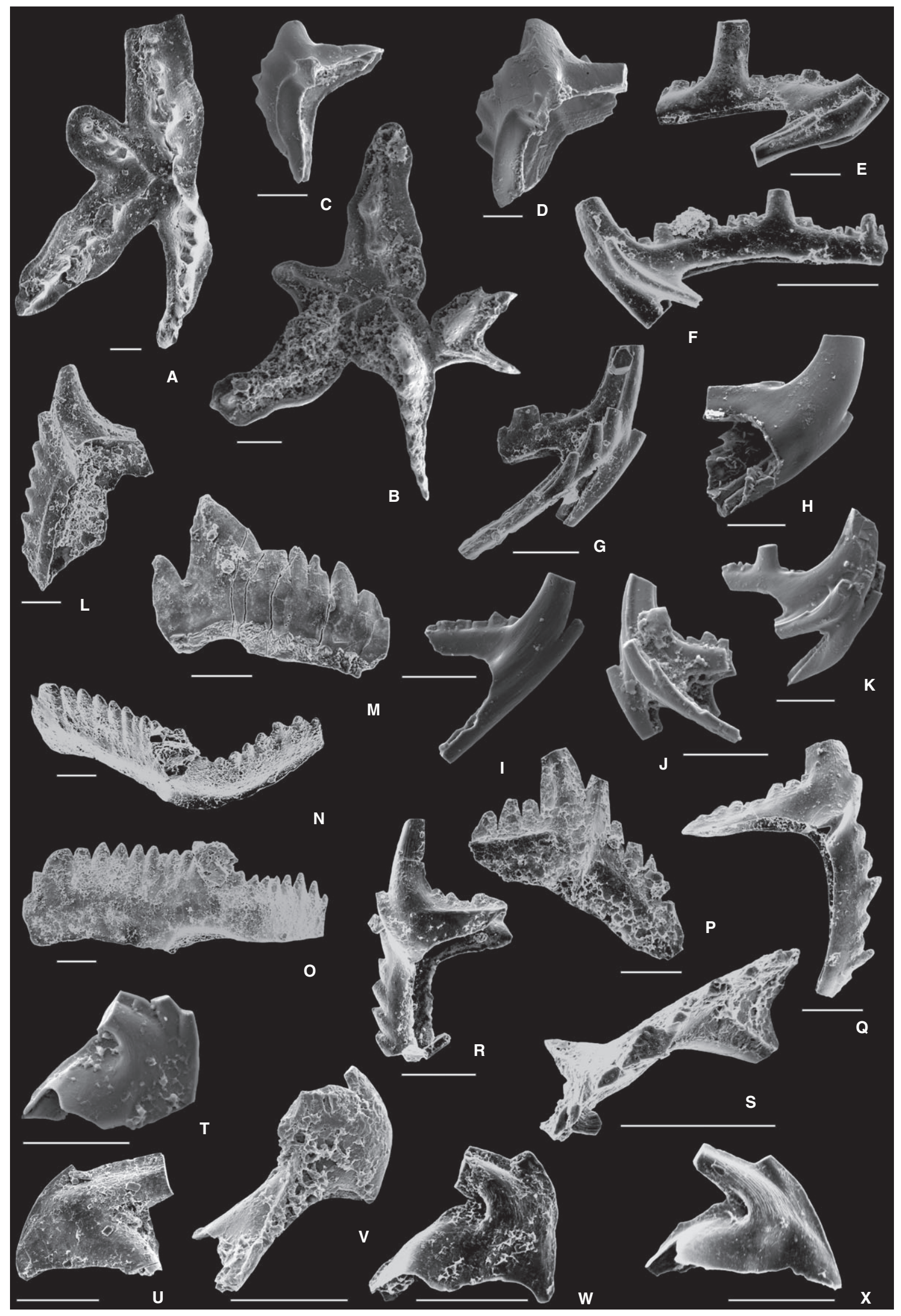


Remarks. The M elements of Amorphognathus are in some respects similar to the $\mathrm{M}$ elements in Rhodesognathus elegans (Rhodes, 1953), but the latter element (Fig. 7R) has typically a reclined cusp and is in this respect reminiscent of the $\mathrm{M}$ element of $A$. tvaerensis. The $\mathrm{M}$ element in $R$. elegans is also characterized by the presence of a long anterior process that carries up to three partially fused denticles in front of the main reclined cusp whose outer margin is smooth and may have a small denticle.

Amorphognathus duftonus Rhodes, 1955 Figures 7D, 12K-Q

\author{
v. 1955 Amorphognathus duftonus sp. nov. Rhodes, \\ p. 123-124, pl. 9, figs $1,3,5,8$. \\ v. 1967 Goniodontus lindstroemi n. sp. Serpagli, p. 41, \\ pl. 16, figs $1-4$. \\ 1980 Amorphognathus lindstroemi (Serpagli, 1967); \\ Orchard, p. 16, pl. 4, fig. 28. \\ 1980 Amorphognathus aff. lindstroemi (Serpagli, 1967); \\ Orchard, pl. 4, fig. 14. \\ v. 1998 Amorphognathus aff. lindstroemi (Serpagli, 1967); \\ Ferretti, pl. 1, fig. 10a-c. \\ v. 1999 Amorphognathus lindstroemi (Serpagli, 1967); \\ Ferretti and Serpagli, pl. 1, fig. 15a-b. \\ v. 2001 Amorphognathus lindstroemi (Serpagli, 1967); \\ Ferretti and Schönlaub, pl. 2, fig. 7. \\ 2008 Amorphognathus ordovicicus Branson and Mehl; \\ Kaljo et al., fig. 8F-G.
}

Material. 130 specimens.

Remarks. Amorphognathus duftonus was first described by Rhodes (1955) based on specimens from the Keisley Limestone. The holotype is a badly broken $\mathrm{Pa}$ element without features useful for species discrimination. However, in the extensive undescribed Keisley Limestone collections at hand (SMB and AF, in prep.), there are numerous well-preserved $\mathrm{Pa}$ elements including almost complete specimens (cf. Bergström and Orchard 1985, pl. 2.5, fig. 1). These are associated with hundreds of $\mathrm{M}$ ele- ments of the type referred to Goniodontus lindstroemi n. sp. by Serpagli (1967), a morphospecies that originally was based on four $\mathrm{M}$ elements from the Upper Ordovician of the Carnic Alps of Italy. In our Keisley Limestone collections, these abundant $\mathrm{M}$ elements are associated with only single $\mathrm{M}$ elements of the type present in A. ordovicicus, and we feel it is appropriate to consider A. lindstroemi as a junior synonym of A. duftonus (cf. Bergström and Leslie 2010). In this species, the $M$ element has a strongly developed outer-lateral keel and a cusp cross-section that is more or less biconvex, rather than subtriangular. Serpagli (1967) also indicated that there is always at least one denticulated process. Orchard (1980, p. 16) redefined this species using as a distinctive characteristic the presence of a barb-like denticle on the antero-lateral face of the cusp in the $\mathrm{M}$ element and observed that this barb-like denticle is the only feature which may currently be used to distinguish A. lindstroemi from A. ordovicicus'. We have also included in A. duftonus, $\mathrm{M}$ elements in which the denticle at the base of the cusp is not clearly developed but is present only as a laterally oriented 'wedge-shaped' costa (Fig. 12N).

Through the Whitland succession, there is a gradual modification of the denticle on the outer edge of the cusp, which becomes better and better defined and tends to be in a more posterior position on the element in the stratigraphically higher samples (Fig. 7D). In the lowermost samples, the specimens have an extended platformlike denticle that is oriented laterally (Figs 12P-Q). The posterior process has a weak edge that extends to the mid-height of the cusp. In samples from the middle part of the Whitland section, the $\mathrm{M}$ elements of this species begin to have a single but definite 'barb-like' denticle that is oriented aborally. Also, the upper edge of the posterior process in the $\mathrm{M}$ element runs along the outer-lateral denticle itself (Fig. 12K). Because they lack an inner process, there is no problem to separate the $\mathrm{M}$ elements of A. duftonus from those of $A$. ventilatus.

Occurrence. $\mathrm{M}$ elements having the morphology of A. duftonus (Fig. 7D) are common through the Sholes-

FIG. 11. A-K, Amorphognathus spp.; A-B, IPUM 28331-28332; Pa elements, upper views; sample levels WW 2 and WW 1; C-D, IPUM 28333-28334; Pb elements, inner-lateral views; sample level WW 2 both; E, IPUM 28335; Sa element, lateral view; sample level WW 12; F-G, IPUM 28336-28337; Sb elements, inner-lateral views; sample levels WW 6 and WW 2; H-I, IPUM 28338-28339; Sc elements, inner-lateral views; sample level WW 2 both; J-K, IPUM 28340-28341; Sd elements, inner-lateral views; sample level WW 2 both. L, ambalodiform element, IPUM 28342; lateral view; sample level WW 12. M-O, Ozarkodina pseudofissilis (Lindström, 1959). M, IPUM 28343; Pb element, lateral view; sample level WW 22. N-O, IPUM 28344; Pa element, upper-lateral and lateral views; sample level RW 7. P-S, Rhodesognathus elegans (Rhodes, 1953); P, S, IPUM 28345 and 28346; Pa elements, lateral and upper views; sample level WW 14 both; Q-R, IPUM 28347-28348; Pb elements, lateral views; sample level WW 2 both. T-X, Gen. et sp. indet. A; T, IPUM 28349; lateral view; sample level WW 6; U, IPUM 28350; lateral view; sample level WW 14; V, IPUM 28351; upper-lateral view; sample level WW 6; W, IPUM 28352; lateral view; sample level WW 6; X, IPUM 28353; lateral view; sample level WW 6. Scale bars represent $100 \mu \mathrm{m}$. 


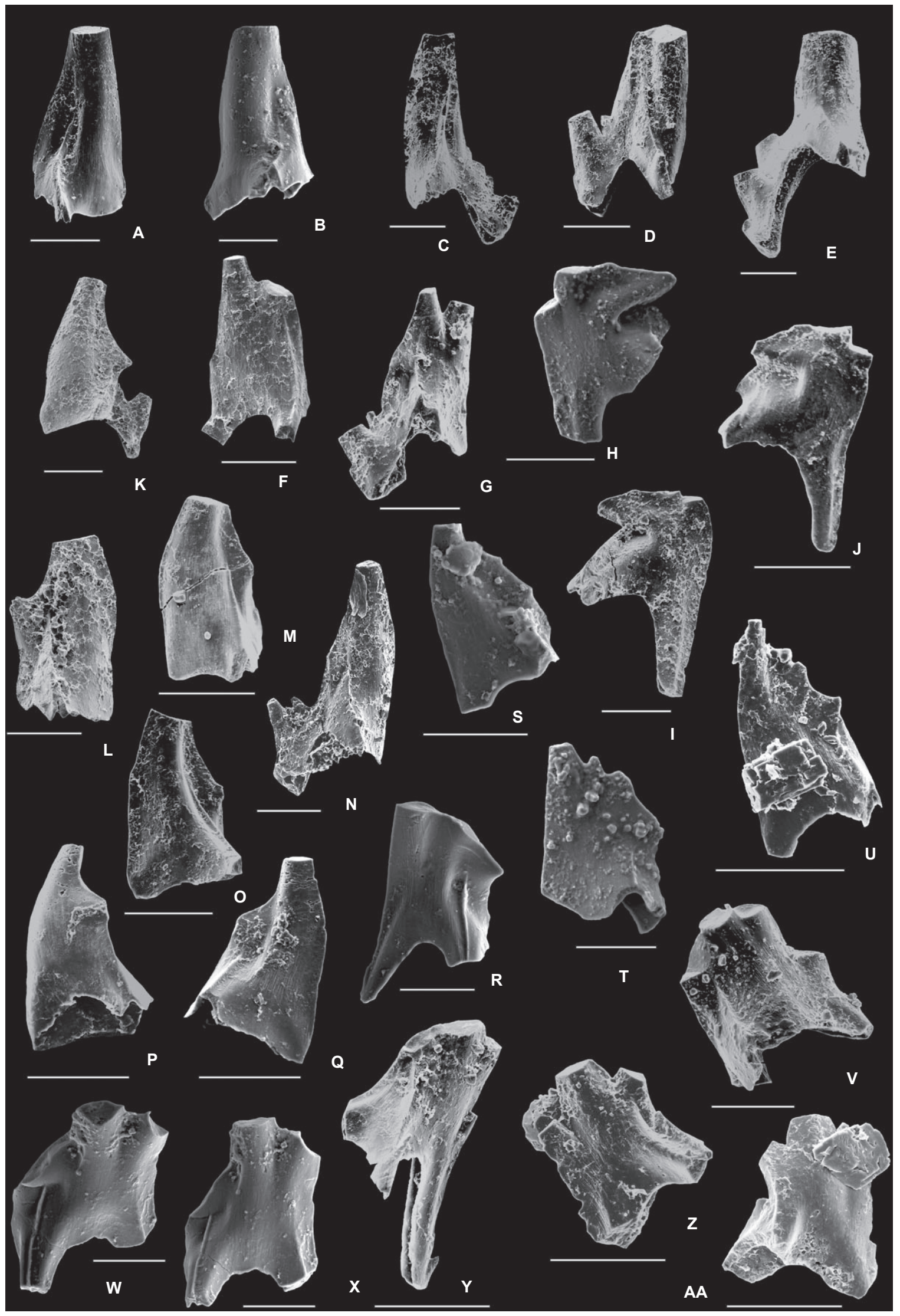


hook Limestone at Whitland. The M element of this species is the most abundant such element recovered from the lowermost part of the Sholeshook Limestone. Starting from sample 7, elements appear that have a well-defined posteriorly oriented denticle, but the keel that runs along the posterior process is not well developed on the lateral denticle.

Amorphognathus ordovicicus Branson and Mehl, 1933 Figures 70, 12A-E

v. 1933 Amorphognathus ordovicicus n. sp. Branson and Mehl, p. 127, pl. 10, fig. 38.

v. 1959 Goniodontus superbus Ethington n. sp., p. 275-279, pl. 40, figs 1-2.

v. 1971a Amorphognathus ordovicicus Branson and Mehl, 1933; Bergström, p. 134-135, pl. 2, figs 6-7.

Material. 242 (M elements).

Remarks. As recently shown by Bergström and Leslie (2010), an M element of A. ordovicicus from the type stratum in the Orchard Creek Shale at Ozora, Missouri, is of a morphologically advanced type characterized by a prominent cusp and poorly developed processes. In general morphology, these $\mathrm{M}$ elements are closely similar to specimens from the late Katian Uggwa Limestone of the Carnic Alps identified as Goniodontus superbus Ethington by Serpagli (1967). These specimens agree morphologically with many elements from the Sholeshook Limestone, and although they show some variation, we consider our identification of the latter as A. ordovicicus as well established.

This species is by far the most common Amorphognathus species in our Whitland collection. Stratigraphically early $\mathrm{M}$ elements have the diagnostic features of the species, such as a single prominent cusp and the absence of an inner-lateral process (Fig. 7O). In stratigraphically early forms, the posterior process runs up to the cusp as an outer-lateral edge, but this edge is not in a median position as in stratigraphically later representatives of the species.

Amorphognathus superbus (Rhodes, 1953) Figures 7S, 12Z-AA

v. 1953 Holodontus superbus n. sp. Rhodes, p. 304, pl. 21, figs $125-127$.

v. 1964 Holodontus superbus Rhodes, 1953; Bergström, p. 26-27, fig. 11.

v. 1971 Amorphognathus superbus (Rhodes, 1953); Bergström, p. 135, pl. 2, figs 8-9.

Material. 22 specimens.

Remarks. Orchard (1980, p. 17) included in A. superbus $\mathrm{M}$ elements that have 'one or more apical denticles, in addition to the cusp, and three distinct processes'. Following the original diagnosis by Rhodes (1953, p. 304), we have here restricted the concept of this species to $M$ elements that possess a cusp and one oral and one aboral denticle and three distinct processes. As noted by some previous authors (Bergström, 1971a, p. 136), dextral Pa elements of $A$. superbus are clearly distinguished from those of A. tvaerensis Bergström, 1962 by the absence of the 'extra' postero-lateral process that is present in the latter species.

$\mathrm{M}$ elements herein assigned to A. superbus bear a definite denticle anterior to the median cusp, an outer-lateral denticle and a long anterior inner-lateral process. The outer-lateral denticle is slightly recurved posteriorly. When preserved, the posterior process has an upper edge that appears to continue along the denticle of the outer-lateral

FIG. 12. A-E, Amorphognathus ordovicicus Branson and Mehl, 1933; A, IPUM 28354; M element, posterior view; sample level WW 6; B, IPUM 28355; M element, posterior view; sample level WW 1; C, IPUM 28356; M element, posterior view; sample level WW 14; D, IPUM 28357; M element, posterior view; sample level WW 14; E, IPUM 28358; M element, posterior view; sample level WW 14. F-G, holodontiform (M) element A; F, IPUM 28359; M element, posterior view; sample level WW 12; G, IPUM 28360; M element, posterior view; sample level WW 14. H-J, Rhodesognathus elegans (Rhodes, 1953); H, IPUM 28361; M element, posterior view; sample level WW 1; I, IPUM 28362; M element, postero-lateral view; sample level WW 14; J, IPUM 28363; M element, postero-lateral view; sample level WW 6. K-Q, Amorphognathus duftonus Rhodes, 1955; K, IPUM 28364; M element, posterior view; sample level WW 15; L, IPUM 28365; M element, posterior view; sample level WW 12; M, IPUM 28366; M element, posterior view; sample level WW 22; N, IPUM 28367; M element, posterior view; sample level WW 15; O, IPUM 28368; M element, posterior view; sample level WW 6; PQ, IPUM 28369; M element, antero-lateral and postero-lateral views; sample level WW 2. R, Amorphognathus aff. A. ventilatus Ferretti and Barnes, 1997, IPUM 28370; M element, posterior view; sample level WW 1; S-U, A. ventilatus Ferretti and Barnes, 1997; S, IPUM 28371; M element, postero-lateral view; sample level WW 1; T, IPUM 28372; M element, posterior view; sample level WW 7; U, IPUM 28373; M element, postero-lateral view; sample level WW 6. V-Y, Amorphognathus cf. A. superbus (Rhodes, 1953); V, IPUM 28374; M element, posterior view; sample level WW 10; W-X, IPUM 28375; M element, upper-postero-lateral and postero-lateral views; sample level WW 1; Y, IPUM 28376; M element, posterior view; sample level WW 6. Z-AA, Amorphognathus superbus (Rhodes, 1953), IPUM 28377; M element, postero-lateral and antero-lateral views; sample level WW 6. Scale bars represent $100 \mu \mathrm{m}$. 


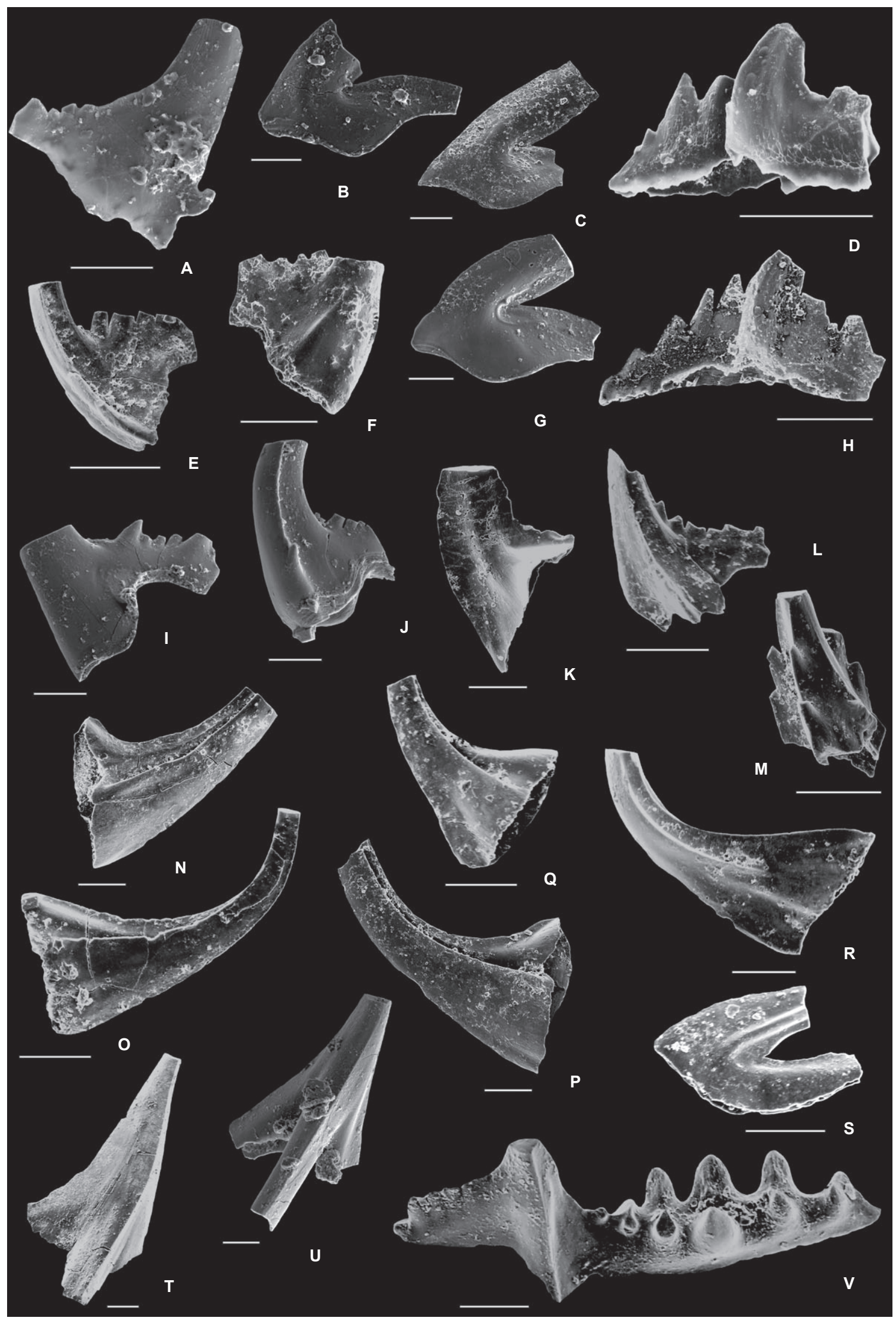


process. The inner-lateral process is adenticulate. Elements with an anterior inner-lateral process that is strongly denticulated also in the proximal part of the process have been tentatively referred to this species (Fig. 12Y).

Orchard (1980) remarked that M elements present in the upper part of the A. superbus Zone retained three well-developed processes, but had no apical accessory denticles at the cusp (cf. Orchard 1980, pl. 4, fig. 21). He considered these $\mathrm{M}$ elements to be transitional to $A$. ordovicicus and assigned them to $A$. aff. superbus. Closely similar $\mathrm{M}$ elements have recently been recovered from the Collingwood Member of the Lindsay Formation in southern Ontario (Zhang et al. 2011, figs 17: 8a-b). This member was referred to the upper A. superbus Zone by Goldman and Bergström (1997).

Occurrence. Elements of A. superbus are present in moderate numbers up to sample level 7 in the lower part of the Whitland section. A few taxonomically uncertain specimens have been found in the middle part of the section.

\section{Amorphognathus ventilatus Ferretti and Barnes, 1997 Figures $7 \mathrm{~V}, 12 \mathrm{~S}-\mathrm{U}$}

1974 Holodontus n. sp. Viira, p. 90, fig. 110 (only).

v. 1997 Amorphognathus ventilatus n. sp. Ferretti and Barnes, p. 28-29, pl. 2, figs 14-17.

Material. 44 specimens.

Remarks. Amorphognathus ventilatus may be distinguished from $A$. duftonus by the presence in the $\mathrm{M}$ element of a well-developed inner anterior process, a more slender cusp and a distinct development of the denticulation on the outer-lateral edge of the cusp. The M element in Rhodesognathus elegans differs from that of A. ventilatus in the presence of a clearly reclined cusp and denticles anterior to the cusp. In terms of morphology of the $\mathrm{M}$ element, A. ventilatus is certainly close to A. superbus and the position of the cusp is critical in separating the two species. In the latter species, the cusp occupies a median position, whereas it is marginal in A. ventilatus. Hence, the critical separating characteristic is the presence or absence of a denticle anterior to the cusp. The $\mathrm{M}$ elements assigned to $A$. ventilatus clearly have a long anterior inner process, which is absent in the corresponding element in A. ordovicicus. Also, the $\mathrm{M}$ element cusp in the latter species is wider and shorter. For these reasons, we regard $A$. ordovicicus and A. ventilatus as separate but closely related species.

Dzik (1999) reported A. ventilatus from a stratigraphically significantly lower interval than the Sholeshook Limestone in the Mójcza Limestone of Poland and introduced a new $A$. ventilatus Zone between the A. tvaerensis and $A$. superbus zones. This zone has subsequently been recognized in several drillcores in the East Baltic (Männik and Viira 2012). However, as noted by Chen et al. (2011, p. 125), there are several problems with this zone as originally described, including that it occurs within an interval that contains A. tvaerensis and Baltoniodus alobatus, which are key index species for the B. alobatus Subzone of the A. tvaerensis Zone in Baltoscandia. As pointed out by Chen et al. (2011), there are also serious doubts that the Mójcza species is conspecific with the stratigraphically much younger A. ventilatus from its type locality in Thuringia (Ferretti and Barnes 1997).

Dzik (1999) suggested that his A. ventilatus from the Mójcza section may represent an ancestral form of the typical species from the Kalkbank of Thuringia. Notably, Dzik (1999) included in A. ventilatus $M$ elements that had one denticle (in 13 among 42 specimens), or even two denticles, anterior to the cusp (2 among 42 specimens), features that he indicated are more typical of A. superbus and A. tvaerensis, respectively, but are in disagreement with Dzik's (1999, p. 246) own diagnosis of A. ventilatus. Among the $102 \mathrm{M}$ elements recovered from the Kalkbank, Ferretti and Barnes (1997) referred 85 to A. ventilatus and 17 to A. ordovicicus. With a possible single exception noted by Dzik (1999), none of these elements has a single denticle anterior to the cusp. The material figured by Dzik (1999) is very fragmentary but judging from the illustrations, some elements referred to

FIG. 13. A-C, E-G, I-J, Hamarodus brevirameus (Walliser, 1964); A, IPUM 28378; Pb element, lateral view; sample level WW 1; B-C, G, IPUM 28379-28381; M elements, lateral views; sample levels WW 1, WW 10 and WW 1. E, IPUM 28382; Sa element, lateral view; sample level WW 2; F, IPUM 28383; Sb element, lateral view; sample level WW 12; I, IPUM 28384; Sc element, lateral view; sample level WW 1; J, IPUM 28385; Sd element, lateral view; sample level WW 1. D, H, K-M, Birksfeldia circumplicata Orchard, 1980; D, H, IPUM 28386 and 28387; Pa elements, lateral views; sample levels WW 2 and WW 7; K, IPUM 28388; M element, lateral view; sample level WW 9; L, IPUM 28389; Sb element, lateral view; sample level WW 2; M, IPUM 28390; ?Sd element, upper-postero-lateral view; sample level WW 7. N-P, Scabbardella altipes (Henningsmoen, 1948); IPUM 28391-28393; lateral views; sample levels WW 2, WW 2 and WW 10. Q-R, Dapsilodus mutatus (Branson and Mehl, 1933); IPUM 28394 and IPUM 28395; lateral views; sample levels WW 2 and WW 6. S, Venoistodus venustus (Stauffer, 1935); IPUM 28396; lateral view; sample level WW 2. T-V, Icriodella superba Rhodes, 1953; T-U, IPUM 283997 and IPUM 28398; Pb elements; lateral views; sample levels WW 12 and WW 1; V, IPUM 28399; Pa element; upper-lateral view; sample level WW 6. Scale bars represent $100 \mu \mathrm{m}$. 


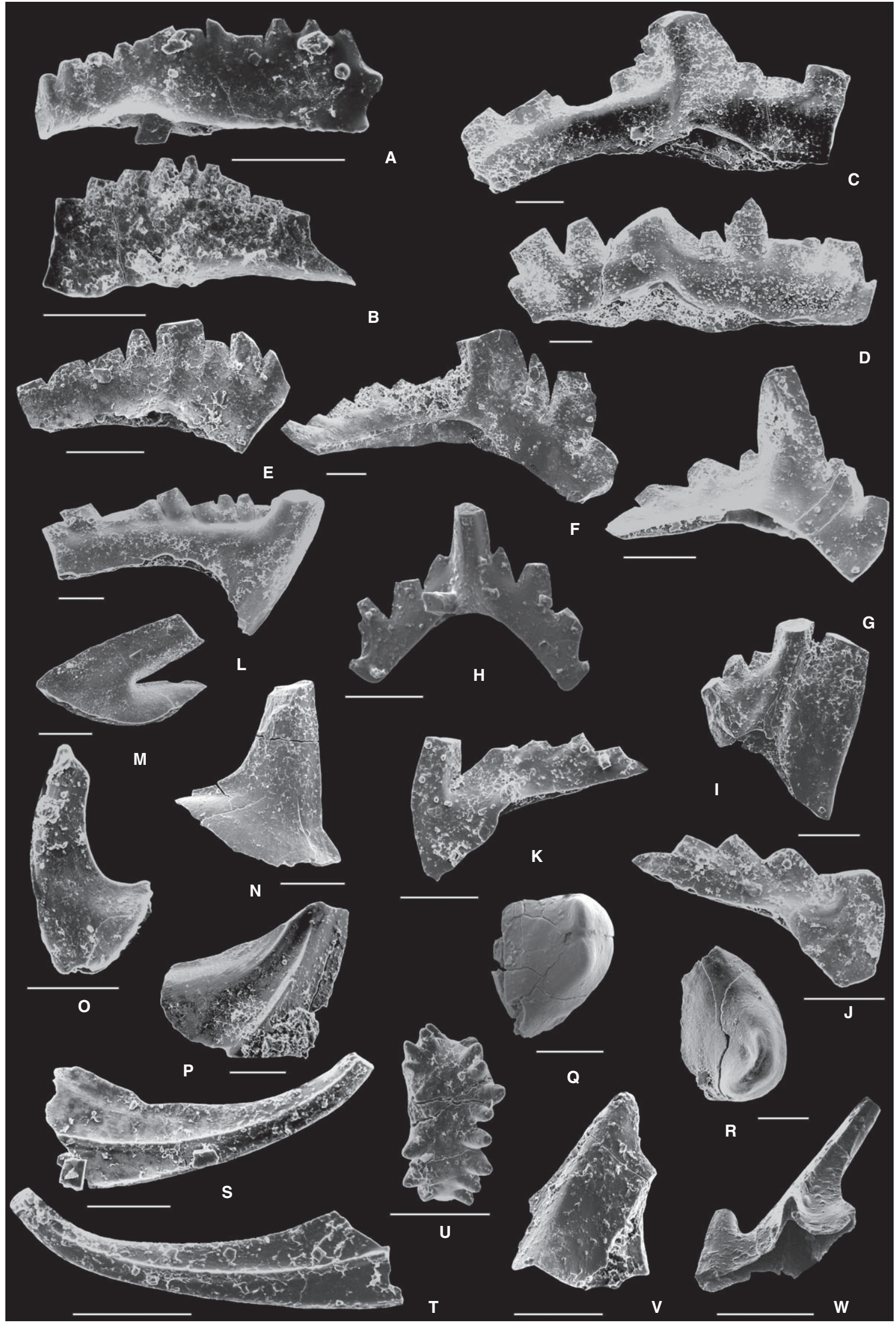


as $A$. aff. ventilatus appear to bear a reclined cusp (e.g. pl. 1, fig. 9), which is a feature typical of the $M$ element of Rhodesognathus elegans, and also have a denticle anterior to the cusp (pl. 1, figs 6,19), a feature herein regarded as characteristic of $A$. superbus.

As far as we are aware, no East Baltic $\mathrm{M}$ elements identified as A. ventilatus have yet been figured. Two specimens kindly provided by Dr P. Männik to one of us (SMB) were sketched in Chen et al. (2011), and these authors regarded them as representing a different morphospecies than A. ventilatus.

Discussion. Dzik (1999, p. 242) regarded the stratigraphic assignment of the Kalkbank, the type stratum of A. ventilatus, as 'somewhat arbitrary' as he considered $\mathrm{M}$ elements with two denticles on the cusp (A. ventilatus sensu Ferretti and Barnes, 1997) and those with only a single cusp (A. ordovicicus sensu Ferretti and Barnes, 1997) as variants of a single morphotype and therefore representing the only Amorphognathus species present in the Kalkbank. However, in his analysis, he did not consider the presence/absence of the inner anterior process as a diagnostic feature. The $\mathrm{M}$ elements assigned to $A$. ventilatus clearly have a long anterior inner process, which is absent in the corresponding element in A. ordovicicus. Also, the $\mathrm{M}$ element cusp in the latter species is wider and shorter. The presence of these two species also in the Whitland collections confirms that $A$. ventilatus occurs in the A. ordovicicus Zone also outside Germany.

Occurrence. Specimens of $A$. ventilatus are present in the lower to middle part of the Whitland section.

Amorphognathus aff. A. ventilatus Ferretti and Barnes, 1997 Figure $12 \mathrm{R}$

Material. Nine specimens.

Remarks. Incomplete $\mathrm{M}$ elements that have an inner anterior process and poorly defined denticles on the outer-lateral edge of the cusp have tentatively been assigned to $A$. aff. A. ventilatus.

Occurrence. Specimens of this taxon are present in the lower-middle part of the Sholeshook Limestone.

\section{Amorphognathus spp.}

Figure 11A-K

Material. 4677 specimens.

Remarks. It is a notable fact that in the lower part of the Whitland section (sample levels 1-6), $\mathrm{Pb}$ and $\mathrm{S}$ elements of Amorphognathus occur in two forms that are of considerably different size. One such form (Fig. 11D, G, K) is in every detail nearly twice as large as the other (Fig. 11C, F, J), but otherwise they are morphologically identical. The two size forms of $\mathrm{Pb}$ elements occur in approximately the same relative abundance in large and small populations, but $\mathrm{S}$ elements of the smaller size are up to four times as common as those of the large size. These unusual abundance ratios could possibly be explained by the presence of taxa that share the same type of ramiform elements (e.g. Rhodesognathus elegans), but from sample level 7 and upwards in the succession, the abundance difference disappears.

Occurrence. Specimens of Amorphognathus spp. are present throughout the study interval in the Whitland section with a definite dominance in the lower-middle part of the Sholeshook Limestone.

\author{
holodontiform (M) element $A$ \\ Figures $7 \mathrm{H}, 12 \mathrm{~F}-\mathrm{G}$
}

v. ?1999 Amorphognathus sp. n. Dzik, p. 246, pl. 2, figs 3-5.

v. ?2001 Amorphognathus sp. A Ferretti and Schönlaub, pl. 1, fig. 9 .

FIG. 14. A-B, Plectodina sp. IPUM 28400 and 28401; Pa elements, lateral views; sample level WW 2 both. C-D, Aphelognathus rhodesi (Lindström, 1959), IPUM 28402 and 28403; Pa elements, lateral view; sample levels WW 8 and WW 12. E-L, Aphelognathus/Plectodina; E, IPUM 28404; ?Pb element, lateral view; sample level WW 17; F-G, IPUM 28405 and 28406; Pb elements, lateral views; sample levels WW 14 and WW 1; H, IPUM 28407; Sa element, posterior view; sample level WW 7; I, IPUM 28408; Sb element, posterior view; sample level WW 12; J-K, IPUM 28409 and 28410; M elements, lateral views; sample levels WW 1 and WW 14; L, IPUM 28411; Sc element, lateral view; sample level WW 11. M-O, Drepanoistodus suberectus (Branson and Mehl, 1933); IPUM 28412-28414; lateral views; sample levels WW 7, WW 12 and WW 2. P, Protopanderodus liripipus Kennedy, Barnes and Uyeno, 1979; IPUM 28415; lateral view. Q-R, Pseuedooneotodus humilis Orchard, 1980; IPUM 28416 and 28417; upper-lateral and upper views; sample levels WW 16 and WW 7. S-T, Walliserodus amplissimus (Serpagli, 1967); IPUM 28418 and 28419; lateral views; sample levels WW 17 and WW 12. U, undetermined; IPUM 28420; sample level WW 7. V-W, Sagittodontina sp.; IPUM 28421 and 28422; P and Sd elements, lateral and lower-lateral views; sample levels WW 16 and WW 12. Scale bars represent $100 \mu \mathrm{m}$. 


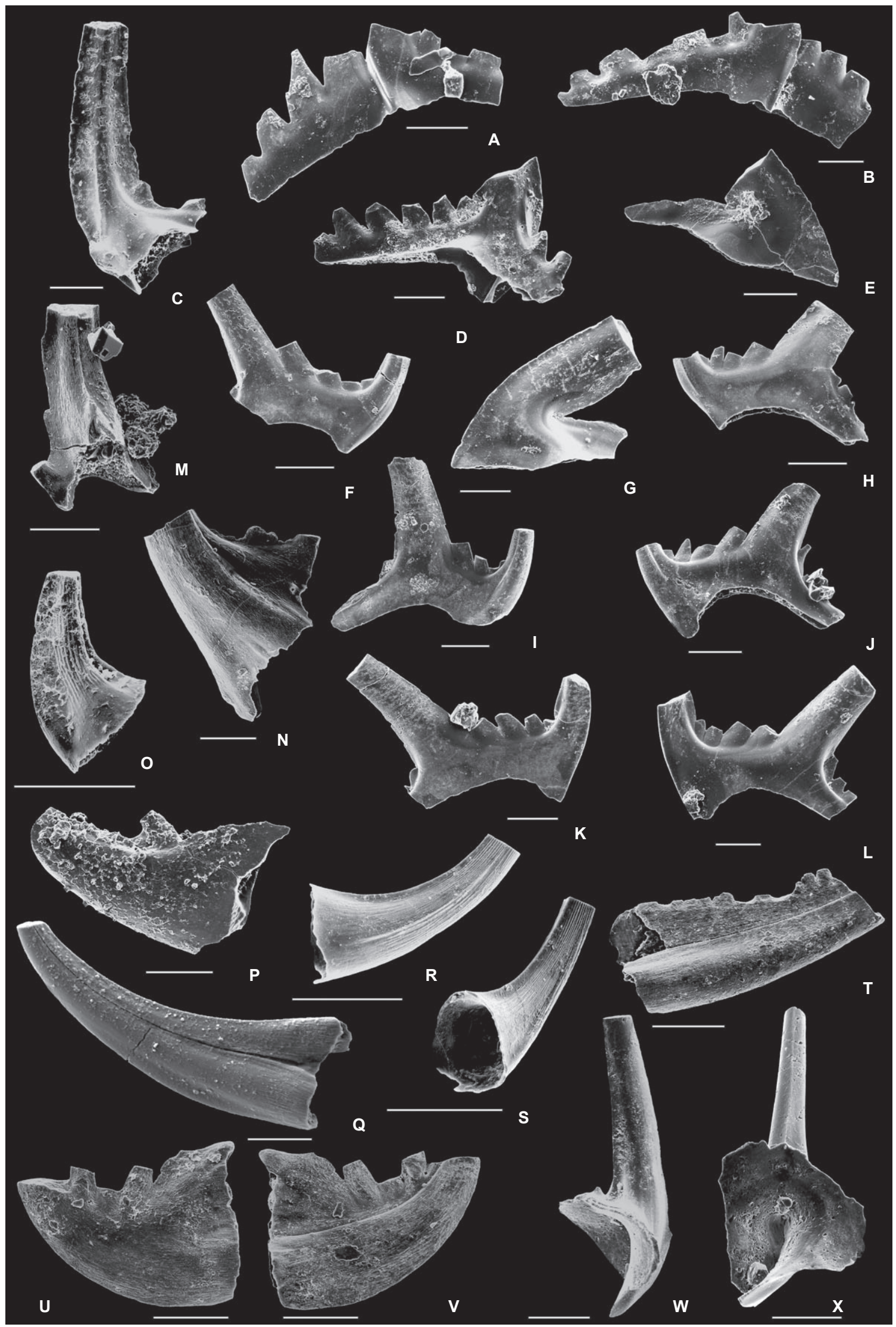


Material. Four specimens.

Remarks. This previously undescribed $\mathrm{M}$ element (Fig. $7 \mathrm{H}$ ), which is represented by only a few specimens, is characterized by having a long main denticle only on the inner side of the cusp that produces a type of bifurcation of the upper edge of the element (Fig. 12F-G). Somewhat similar elements were reported by Dzik (1999) and Ferretti and Schönlaub (2001), but the Whitland specimens differ in apparently having an inner anterior process.

Occurrence. Specimens of the holodontiform (M) element $\mathrm{A}$ are present in the lower-middle part of the Whitland section.

\section{holodontiform (M) element B Figure 17A-D}

Material. Two specimens.

Remarks. Two massive M elements from the basal part of the Sholeshook Limestone are much larger than the other $\mathrm{M}$ elements and possess a complete outer-lateral denticulated process and also have a denticle anterior to the cusp. Because the cusp is broken, no species assignment is possible. Similar massive $M$ elements were figured by Dzik (1999, pl. 2, fig. 11) who referred to them as Amorphognathus sp. n. The two Whitland M elements clearly lack the inner anterior process so they are not referable to A. superbus.

Occurrence. Only present in the WW1 sample from the basal part of the Sholeshook Limestone.

Eocarniodus aff. E. gracilis (Rhodes, 1955)

Figures 10, 16B-D, F-P, R-V

Material. 4452 specimens.
Remarks. Orchard (1980) proposed a new monospecific genus Eocarniodus to include minute conodont elements with a subcentral cusp and two short denticulated processes. Such elements were previously often regarded as process fragments of ramiform elements. Many such elements in the Whitland samples certainly include such fragments (mainly of species of Amorphognathus), but the elements we include in E. aff. E. gracilis are in many cases of too large size to be possible fragments of processes. Furthermore, the margin of the basal cavity appears complete in many specimens with no indication of any fracture. Such apparently complete specimens are herein referred to E. aff. E. gracilis.

The array of elements and their arrangement in the Eocarniodus apparatus are not yet firmly established, and Orchard's (1980) references to $\mathrm{Pa}, \mathrm{Pb}, \mathrm{M}$ and $\mathrm{S}$ elements were provisional. We have not recovered any platformlike elements of the $\mathrm{Pa} / \mathrm{Pb}$ type described by Orchard (1980). On the contrary, an extremely rare element (Fig. 16B-D) shows a definite hint of the presence of a third median process and might be a $\mathrm{Pa}$ element. Another element type, a questionable $\mathrm{M}$ element (Fig. 16G-H), has a symmetrical outline with a prominent cusp and short denticulated processes on both its sides. Another type of element (Fig. 16K-O) is flexed and shows similarity to the last-mentioned one in the organization of the denticles but has a pronounced arching of the blade. Other elements (Fig. 16R-S) have a main cusp with denticles only on one side and faint striae on the surface of the specimen and could represent Sc elements. A common element, possibly an Sb element (Fig. 16I-J, P, T$\mathrm{V})$, possesses a main cusp with denticles on both sides of the cusp and exhibits a process arched downward and/or slightly flexed laterally. Although our collection of Eocarniodus specimens is reasonably large, we are unable to present an adequate reconstruction of the apparatus.

Occurrence. This taxon is present throughout the Sholeshook Limestone and is dominant in its lower-middle part.

FIG. 15. A-L, Phragmodus undatus Branson and Mehl, 1933; A-B, IPUM 28423 and 28424; Pa elements, lateral views; sample level WW 22 both; C-D, IPUM 28425 and 28426; Pb elements, lateral views; sample level WW 22 both; E, G, IPUM 28427 and 28428 ; M elements, lateral views; sample level WW 22 both; F, H, IPUM 28429 and 28430; Sa elements, lateral views; sample level WW 22 both; I-J, IPUM 28431 and 28432; Sb elements, lateral views; sample level WW 22 both; K-L, IPUM 28433 and 28434; Sc elements, lateral views; sample level WW 22 both. M-N, Birksfeldia circumplicata Orchard, 1980; M, IPUM 28435; Sa element, posterior view; sample level WW 20; N, IPUM 28436; Sb element, lateral view; sample level WW 20. O, Decoriconus costulatus Rexroad, 1967; IPUM 28437; lateral view; sample level WW 15. P, Belodina/Eobelodina sp.; IPUM 28438; lateral view; sample level WW 12. Q, Panderodus sp. 2. IPUM 28439; lateral view; sample level WW 7. R-S, Staufferella cf. S. inaligera McCracken and Barnes, 1981; IPUM 28440; lateral and postero-lateral views; sample level WW 23. T, Panderodus serratus Rexroad, 1967; IPUM 28441; lateral view; sample level WW 20. UV, Belodina cf. B. confluens Sweet, 1979b; IPUM 28442; lateral views; sample level WW 20. W-X, gen. et sp. indet. B; IPUM 28443; postero-lateral and posterior views; sample level WW 22. Scale bars represent $100 \mu \mathrm{m}$. 


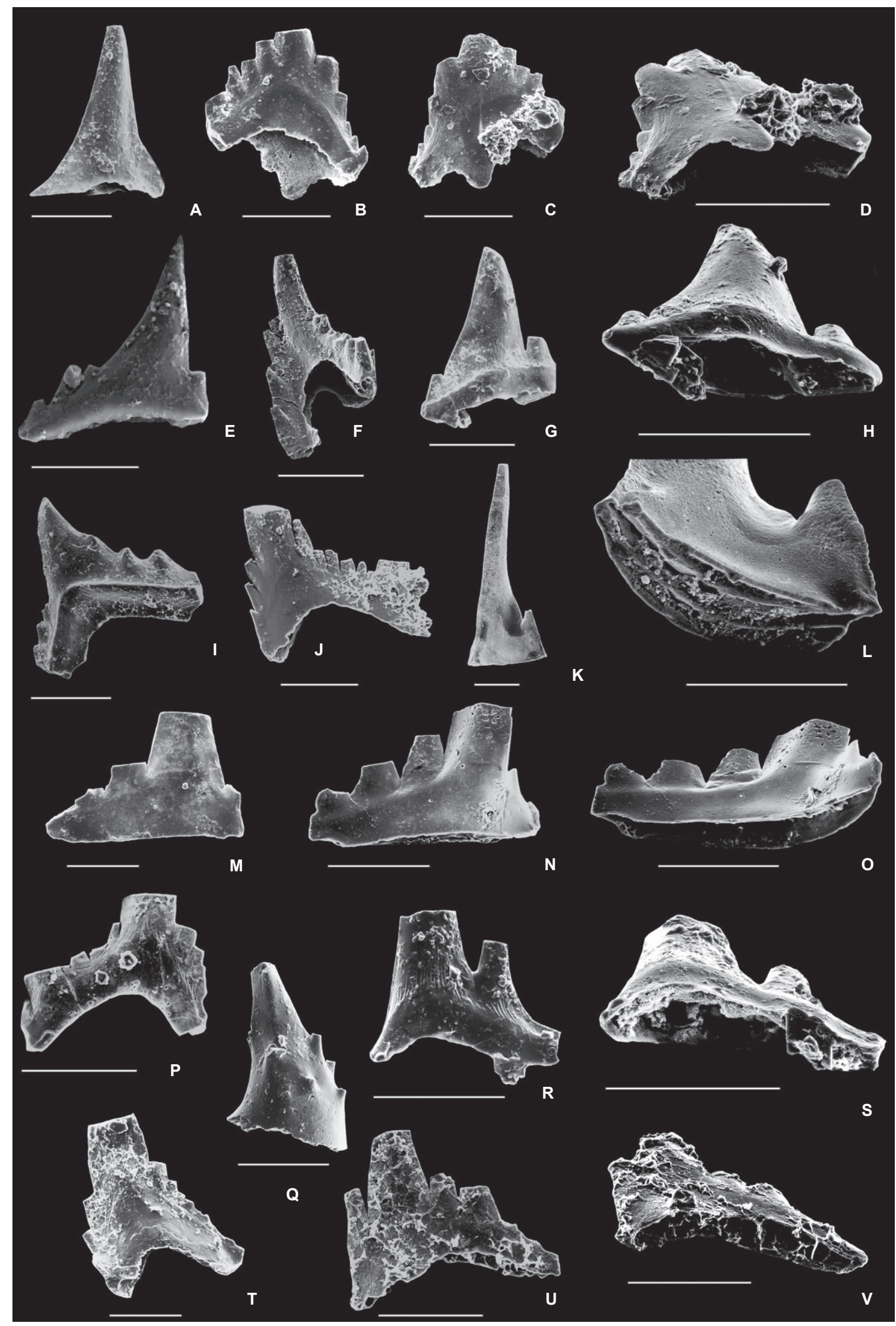


Gen. et sp. indet. A

Figure $11 \mathrm{~T}-\mathrm{X}$

Material. 76 specimens.

Description. Our collections from the Sholeshook Limestone include a distinctive 'falodiform' element that has generally one (Fig. 11U-X), or rarely two (Fig. 11T), prominent denticles along the anterior margin of the proclined or reclined cusp with keeled edges. The cusp is broken off in our specimens but the element has a straight or somewhat curved basal margin with a distinct undulation approximately one-third of the distance between the antero-basal corner and the postero-basal corner. The base is strongly compressed anteriorly but widens posteriorly and has a flat inner face and a convex outer face. The antero-basal and oral-basal angles are about 70 and 45 degrees, respectively. The oral edge is keeled and nondendiculate.

Remarks. Our specimens resemble a specimen described as Falodus n. sp. by Bergström (1962), which clearly represents the $\mathrm{M}$ element of Periodon grandis (Ethington, 1959). However, they are distinguished by having a single prominent anterior denticle (or maximum two denticles) rather than a series of denticles as in the Swedish, stratigraphically older, specimens. The Whitland specimens are clearly distinguished from the $\mathrm{M}$ element of Rhodesognathus elegans by the absence of an inner-lateral process and from the $\mathrm{M}$ element of Hamarodus brevirameus by the presence of a denticle along the cusp anterior margin and the presence of a prominent lateral bulge on the base.

Occurrence. Present in the lower-middle part of the Sholeshook Limestone from basal sample 1 up to sample 17.

\section{CONCLUSIONS}

The conodont collection of about 17000 conodont elements isolated from 17 samples from the Sholeshook Limestone at the Highway A40 road cut west of Whitland, South Wales, is the most abundant and taxonomically diverse conodont fauna so far obtained from any Ordovician stratigraphic unit in the British Isles. Based on our study of this collection, a few general conclusions can be presented.

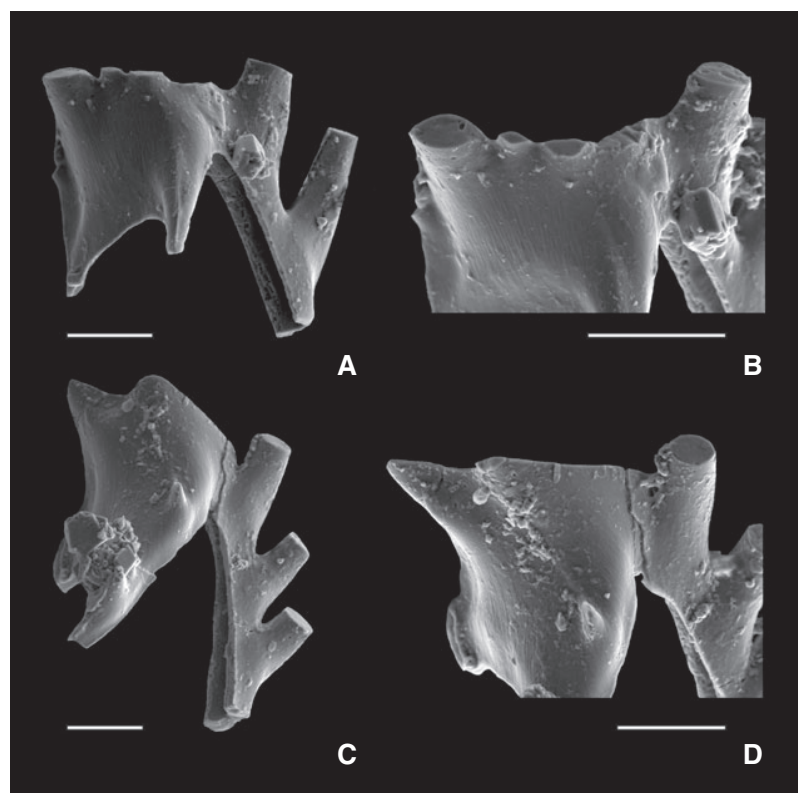

FIG. 17. Holodontiform (M) element B. A-B, IPUM 28459; $\mathrm{M}$ element, posterior and upper-posterior views; sample level WW 1. C-D, IPUM 28460; M element, posterior and upper-posterior views; sample level WW 1. Scale bars represent $100 \mu \mathrm{m}$.

1. A biostratigraphical assessment indicates that the Sholeshook Limestone is referable to the lower portion of the Amorphognathus ordovicicus Zone and is approximately coeval with Cautleyan Zone 2 of the Ashgill Series in its type area in northern England. The close correlation recognized in this interval between conodont, graptolite and chitinozoan zones permits the establishment of a refined biostratigraphy of an important part of the Ashgill Series. Furthermore, the data at hand also allow a more precise correlation of this interval with units in Baltoscandia, Thuringia and the North American Midcontinent than those presented in recently published summaries of Ordovician stratigraphy in the UK and globally (Cooper and Sadler 2012). Hence, the present study shows that the Cautleyan Zone 2 (and probably Zone 3) correlates with the Baltoscandian Nabala Stage of the Harju Series and with the lower Richmondian Stage of the North American Cincinnatian Series.

FIG. 16. A, E, Istorinus sp.; IPUM 28444 and 28445; lateral views; sample levels WW 7 and WW 1. B-D, F-P, R-V. Eocarniodus aff. E. gracilis (Rhodes, 1955); B-D, IPUM 28446; ?Pa element, anterior, posterior and lower-posterior views; sample level WW 2; F, IPUM 28447; ?Sa element, postero-lateral view; sample level WW 7; G-H, IPUM 28448; ?M element, lateral and lower-lateral views; I-J, IPUM 28449 and 28450; ?Sb elements, lateral views; sample levels WW 12 and WW 6; K-L, IPUM 28451; ?M element, lateral and lower-lateral views; sample level WW 20; M-O, IPUM 28452 and 28453 (N-O); ?M elements, lateral, lateral and lower-lateral views; sample level WW 22 all; P, IPUM 28454; ?Sb element, lateral view; sample level WW 6. Q, ?Hirsutodontus sp.; IPUM 28458; lateral view; sample level WW 15. R-S, IPUM 28455; ?Sc element, lateral and lower-lateral views; sample level WW 2; T-V, IPUM 28456 and 28457 (U-V); ?Sb elements, lateral, lateral and lower-lateral views; sample levels WW 9 and WW 14. Scale bars represent $100 \mu \mathrm{m}$. 
2. The composition of the conodont fauna with dominance of representatives of Amorphognathus, Eocarniodus, Aphelognathus/Plectodina, Dapsilodus and Birksfeldia, which is typical of equivalent faunas from the British Province, shows some similarity to that of coeval faunas from the Baltoscandic Province, but differs in significant ways from those of the Mediterranean Province, and even more from those of the Red River and Ohio Valley provinces in the North American Midcontinent.

3. The otherwise sparse but species-diagnostic M elements of Amorphognathus, which are common in the Sholeshook fauna, show an unexpected and puzzling morphological variation suggesting a speciation event.

Acknowledgements. The authors would like to thank C. Gentilini (Università di Modena e Reggio Emilia, Italy) and M. Tonelli (Centro Interdipartimentale Grandi Strumenti, CIGS, Modena, Italy) for their assistance during the SEM-EDX investigations. SMB is indebted to Kungliga Fysiografiska Sällskapet (Royal Physiographical Society) in Lund for grants that covered part of the cost for his studies of British Ordovician localities. CRB acknowledges financial support towards this work from the Natural Sciences and Engineering Research Council of Canada. We acknowledge useful comments on the manuscript by Svend Stouge, Steven Leslie, Sally Thomas and an anonymous reviewer. This paper is a contribution to the IGC Project 591 'The Early to Middle Palaeozoic Revolution-Bridging the gap between the Great Ordovician Biodiversification Event and the Devonian Terrestrial Revolution'.

Editor. Phil Lane

\section{DATA ARCHIVING STATEMENT}

Data for this study are available in the Dryad Digital Repository: http://dx.doi.org/10.5061/dryad.j673f

\section{REFERENCES}

AN, T. X. 1987. Paleozoic conodonts of southern China. Science Press, Beijing, 238 pp.

BAARS, C. 2013. Rugose corals from the Upper Ordovician Sholeshook Limestone of southwest Wales with an assessment of the coral affinities and biofacies. Geological Journal, 48, 603-619.

BARNES, C. R. and WILliAMS, S. H. 1988. Conodonts from the Ordovician-Silurian Boundary Stratotype, Dob's Linn, Scotland. Bulletin of the British Museum of Natural History (Geology), 43, 31-39.

BERGSTRÖM, S. M. 1962. Conodonts from the Ludibundus Limestone (Middle Ordovician) of the Tvären area (S.E. Sweden). Arkiv for Geologi och Mineralogi, 3, 1-61.
1964. Remarks on some Ordovician conodont faunas from Wales. Acta Universitatis Lundensis, II (3), 1-67.

— 1971a. Conodont biostratigraphy of the Middle and Upper Ordovician of Europe and eastern North America. 83-157. In SWEET, W. C. and BERGSTRÖM, S. M. (eds). Symposium on conodont biostratigraphy. Geological Society of America Memoir, 127, 499 pp.

1971b. Correlation of the North Atlantic Middle and Upper Ordovician conodont zonation with the graptolite succession. Mémoires du Bureau de Recherches Géologiques et Minières, 73, 177-187.

1978. Middle and Upper Ordovician conodont and graptolite biostratigraphy of the Marathon, Texas graptolite zone reference standard. Palaeontology, 21, 723-758.

— 1983. Biogeography, evolutionary relationships, and biostratigraphic significance of Ordovician platform conodonts. Fossils and Strata, 15, 35-58.

_ 1990. Biostratigraphic and biogeographic significance of Middle and Upper Ordovician conodonts in the Girvan succession, south-west Scotland. Courier Forschungsinstitut Senckenberg, 118, 1-43.

- 2007. The Ordovician conodont biostratigraphy of the Siljan region south-central Sweden. A brief review of an international reference standard. Sveriges Geologiska Undersökning (Geological Survey of Sweden) Rapporter och Meddelanden, 128, 26-41, 63-78.

— and LESLIE, S. A. 2010. The Ordovician zone index conodont Amorphognathus ordovicicus Branson \& Mehl, 1933 from its type locality and the evolution of the genus Amorphognathus Branson \& Mehl, 1933. Journal of Micropalaeontology, 29, 73-80.

— and MACKENZIE, P. 2005. Biostratigraphic and paleoceanographic relations between the type Richmondian (Upper Ordovician) in the Cincinnati region and the Upper Mississippi Valley succession. Iowa Geological Survey Guidebook Series, 24, 34-37.

— and MASSA, D. 1992. Stratigraphic and biostratigraphic significance of Upper Ordovician conodonts from northwestern Libya. 1323-1342. In SALEM, M. J., HAMMUDA, O. S. and ELIAGOUBI, B. A. (eds). The Geology of Libya, Vol. IV. Elsevier Science Publishers, Amsterdam, 1624 pp.

— and ORCHARD, M. J. 1985. Conodonts of the Cambrian and Ordovician Systems from the British Isles. 32-67. In HIGGINS, A. C. and AUSTIN, R. L. (eds). A stratigraphical index of conodonts. Ellis Horwood Limited, Chichester, 263 pp.

— and SWEET, W. C. 1966. Conodonts from the Lexington Limestone (Middle Ordovician) of Kentucky and its lateral equivalents in Ohio and Indiana. Bulletins of American Paleontology, 50, 269-439.

_ RHODES, F. H. T. and LindströM, M. 1987. Conodont biostratigraphy of the Llanvirn-Llandeilo and the Llandeilo-Caradoc Series boundaries in the Ordovician System of Wales and the Welsh Borderland. 294-315. In AUSTIN, R. L. (ed.). Conodonts: investigative techniques and applications. Ellis Horwood Limited, Chichester, $422 \mathrm{pp}$.

- XU CHEN, GUTIÉRREZ-MARCO, J. C. and DRONOV, A. 2009. The new chronostratigraphic classification of the Ordovician System and its relations to major regional ser- 
ies and stages and to $\delta^{13} \mathrm{C}$ chemostratigraphy. Lethaia, 42, 97 107.

- SCHMiTZ, B., YOUNG, S. and BRUTON, D. L. 2011a. Lower Katian (Upper Ordovician) $\delta^{13} \mathrm{C}$ chemostratigraphy, global correlation and sea-level changes in Baltoscandia. GFF, 133, 1-17.

- CALNER, M., LEHNERT, O. and NOOR, A. $2011 b$. A new upper Middle Ordovician-Lower Silurian drillcore standard succession from Borenshult in Östergötland, southern Sweden. 1. Stratigraphical review with regional comparisons. GFF, 133, 149-171.

- LEHNERT, O., CALNER, M. and JOACHIMSKI, M. M. 2012. A new upper Middle Ordovician-Lower Silurian drillcore standard succession from Borenshult in Östergötland, southern Sweden. 2. Significance of $\delta^{13} \mathrm{C}$ chemostratigraphy. GFF, 134, 39-63.

BRANSON, E. B. and MEHL, M. G. 1933. Conodonts from the Maquoketa Thebes (Upper Ordovician) of Missouri. University of Missouri Studies, 8, 121-132.

BRENCHLEY, P. J., RUSHTON, A. W. A., HOWELlS, M. and CAVE, R. 2006. Cambrian and Ordovician in the Early Palaeozoic tectonostratigraphic evolution of the Welsh Basin, Midland and Monian terranes of eastern Avalonia. 2572. In BRENCHLEY, P. J. and RAWSON, P. E. (eds). The Geology of England and Wales, Second edition. The Geological Society, London, $559 \mathrm{pp}$.

CHEN, X., BERGSTRÖM, S. M., ZHANG, Y. D., GOLDMAN, D. and CHEN, Q. 2011. Upper Ordovician (Sandbian-Katian) graptolite and conodont zonation in the Yangtze region, China. Earth and Environmental Science Transactions of the Royal Society of Edinburgh, 101, 111-134.

COOPER, R. A. and SADLER, P. M. 2012. Chapter 20: The Ordovician Period. 489-523. In GRADSTEIN, F. M., OGG, J. G., SCHMITZ, M. D. and OGG, G. M. (eds). The Geological Time Scale 2012. Elsevier, Amsterdam, 1176 pp.

DEL MORAL, B. and SARMIENTO, G. N. 2008. Conodontos del Katiense (Ordovicico Superior) del sector meridional de la Zone Centroibérica (España). Revista de Micropaleontologia, 40, 169-245.

DRESBACH, R. L. 1983. Conodont biostratigraphy of the Middle and Upper Ordovician Viola Group of the south-central Oklahoma Arbuckle Anticline. Unpublished MSc thesis, The Ohio State University, Columbus, 202 pp.

DZIK, J. 1984. Early Ordovician conodonts from the Barrandian and Bohemian-Baltic faunal relationships. Acta Palaeontologica Polonica, 28, 327-368.

1999. Evolution of the Late Ordovician high-latitude conodonts and dating of Gondwana glaciations. Bollettino della Società Paleontologica Italiana, 37, 237-253.

EPSTEIN, A. G., EPSTEIN, J. B. and HARRIS, L. D. 1977. Conodont color alteration - an index to organic metamorphism. US Geological Survey Professional Paper, 995, G1-G27.

ETHINGTON, R. L. 1959. Conodonts of the Ordovician Galena Formation. Journal of Paleontology, 33, 257-292.

FERRETTI, A. 1992. Biostratigrafia a conodonti del margine settentrionale del Gondwana (Ordoviciano sup.-Ashgill). Unpublished PhD thesis, University of Modena, 281 pp.
- 1998. Late Ordovician conodonts from the Prague Basin, Bohemia. 123-137. In SZANIAWSKI, H. (ed.). Proceedings of the Sixth European Conodont Symposium (ECOS VI). Palaeontologia Polonica, 58, 123-139.

— and BARNES, C. R. 1997. Upper Ordovician conodonts from the Kalkbank limestone of Thuringia, Germany. Paleontologia, 40, 15-42.

— and SCHÖNLAUB, H. P. 2001. New conodont faunas from the Late Ordovician of the Central Carnic Alps, Austria. Bollettino della Società Paleontologica Italiana, 40, 3-15.

— and SERPAGLI, E. 1991. First record of Ordovician conodonts from southwestern Sardinia. Rivista Italiana di Paleontologia e Stratigrafia, 97, 27-34.

- 1999. Late Ordovician conodont faunas from southern Sardinia, Italy: biostratigraphic and paleogeographic implications. 215-236. In SERPAGLI, E. (ed.). Studies on Conodonts: Proceedings of the Seventh International Symposium on Conodonts. Bollettino della Società Paleontologica Italiana, 37, $557 \mathrm{pp}$.

_ BERGSTRÖM, S. M., and BARNES, C. R. 2013. Data from: Katian (Upper Ordovician) conodonts from Wales. Dryad Data Repository. http://dx.doi.org/10.5061/dryad.j673f

FORTEY, R. A., HARPER, D. A. T., INGHAM, J. K., OWEN, A. W. and RUSHTON, A. W. A. 1995. A revision of the Ordovician series and stages in the historical type area. Geological Magazine, 132, 15-30.

PARKES, M. A., RUSHTON, W. A. and WOODCOCK, N. H. 2000. A revised correlation of Ordovician rocks in the British Isles. Geological Society London Special Report, 24, 1-83.

FUCHS, A. 1989. Zur Stratigraphie der Gräfenthaler Schichten (Ordovizium) in Thüringen auf der Grundlage von Conodontenuntersuchungen. Veröffentlichungen Naturhistorisches Museum Schloß Bertholdsburg Schleusingen, 4, 78-82.

— 1990. Bemerkungen zu Stratigraphie und Character der ordovizischen Conodontenfauna Thüringens. Neues Jahrbuch für Geologie und Paläontologie, Monatshefte, 4, 193-214.

FUGANTI, A. and SERPAGLI, E. 1968. Geological remarks on Urbana Limestone and evidence for its Upper Ordovician age by means of conodonts-eastern Sierra Morena, South Spain. Bollettino della Società Geologica Italiana, 87, 511-521.

GLENISTER, A. T. 1957. The conodonts of the Ordovician Maquoketa Formation in Iowa. Journal of Paleontology, 31, 715-736.

GOLDMAN, D. and BERGSTRÖM, S. M. 1997. Late Ordovician graptolites from the North American Midcontinent. Palaeontology, 40, 965-1010.

GRAHN, Y. and NÕLVAK, J. 2010. Swedish Ordovician chitinozoa and biostratigraphy: a review and new data. Palaeontographica, Abteilung B, 283, 5-71.

HENNINGSMOEN, G. 1948. The Tretaspis Series of the Kullatorp Core. Bulletin of the Geological Institution of the University of Uppsala, 32, 374-432.

INGHAM, J. K. 1966. The Ordovician rocks in the Cautley and Dent Districts of Westmorland and Yorkshire. Proceedings of the Yorkshire Geological Society, 35, 455-505. 
KALJO, D., HINTS, L., MÄNNIK, P. and NÕLVAK, J. 2008. Succession of Hirnantian events based on data from Baltica: brachiopods, chitinozoans, conodonts and carbon isotopes. Estonian Journal of Earth Sciences, 57, 197-218.

KENNEDY, D. J., BARNES, C. R. and UYENO, T. T. 1979. A Middle Ordovician conodont faunule from the Tetagouche Group, Camel Back Mountain, New Brunswick. Canadian Journal of Earth Sciences, 16, 540-551.

KNÜPFER, J. 1967. Zur Fauna und Biostratigraphie der Ordoviciums (Gräfenthaler Schichten) in Thüringen. Freiberger Forschungshefte, C220, 1-119.

KOHUT, J. J. and SWEET, W. C. 1968. The American Upper Ordovician Standard. X. Upper Maysville and Richmond conodonts from the Cincinnati region of Ohio, Indiana, and Kentucky. Journal of Paleontology, 42, 1456-1477.

LINDSTRÖM, M. 1959. Conodonts from the Crug Limestone (Ordovician, Wales). Micropaleontology, 5, 427-452.

— 1971. Lower Ordovician conodonts of Europe. 21-61. In SWEET, W. C. and BERGSTRÖM, S. M. (eds). Symposium on Conodont biostratigraphy. Geological Society of America Memoir, 127, 499 pp.

MÄNNIK, P. and VIIRA, V. 2012. Ordovician conodont diversity in the northern Baltic. Estonian Journal of Earth Sciences, 61, 1-14.

MATTHEWS, S. C. 1973. Notes on open nomenclature and on synonymy lists. Palaeontology, 16, 713-719.

McCRACKEN, A. D. and BARNES, C. R. 1981. Conodont biostratigraphy and paleoecology of the Ellis Bay Formation, Anticosti Island, Québec, with special reference to Late Ordovician-Early Silurian chronostratigraphy and the systemic boundary. Geological Survey of Canada Bulletin, 329, 51-134.

NIELSEN, A. T. 2004. Ordovician sea level changes: a Baltoscandian perspective. 84-93. In WEBBY, B. D., PARIS, F., DROSER, M. and PERCIVAL, I. (eds), The great Ordovician biodiversification event. Columbia University Press, New York, 484 pp.

NÕLVAK, J. and GRAHN, Y. 1993. Ordovician chitinozoan zones from Baltoscandia. Review of Palaeobotany and Palynology, 79, 245-269.

ORCHARD, M. J. 1980. Upper Ordovician conodonts from England and Wales. Geologica et Palaeontologica, 14, 9-44.

— 1985. Conodont localities. 33-46. In BERGSTRÖM, S. M. and ORCHARD, M. J., Conodonts from the Cambrian and Ordovician Systems from the British Isles. In HIGGINS, A. C. and AUSTIN, R. L. (eds). A stratigraphical Index of Conodonts. Ellis Horwood Lmt, Chichester, 259 pp.

PRICE, D. 1973. The age and stratigraphy of the Sholeshook Limestone of southwest Wales. Geological Journal, 8, 225-246.

— 1977. Species of Tretaspis (Trilobita) from the Ashgill Series in Wales. Palaeontology, 20, 763-792.

1980. A revised age and correlation for the topmost Sholeshook Limestone Formation (Ashgill) of South Wales. Geological Magazine, 117, 485-489.

— 1984. The Pusgillian Stage in Wales. Geological Magazine, 121, 99-105.

REXROAD, C. B. 1967. Stratigraphy and conodont paleontology of the Brassfield (Silurian) in the Cincinnati Arch Area. Indiana Geological Survey Bulletin, B36, 64 pp.
RHODES, F. H. T. 1953. Some British Lower Palaeozoic conodont faunas. Philosophical Transactions of the Royal Society of London Series B, 237 (647), 261-334.

— 1955. The conodont fauna of the Keisley Limestone. Quarterly Journal of the Geological Society of London, 111, 117-142.

RICKARDS, R. B. 2002. The graptolitic age of the type Ashgill Series (Ordovician), Cumbria, UK. Proceedings of the Yorkshire Geological Society, 54, 1-16.

SARMIENTO, G. N. 1990. Conodontos de la Zona ordovicicus (Ashgill) en la Caliza Urbana, Corral de Calatrava (Ciudad Real). Geogaceta, 7, 54-56.

SAVAGE, N. M. and BASSETT, M. G. 1985. Caradoc-Ashgill conodont faunas from Wales and the Welsh Borderland. Palaeontology, 28, 679-713.

SERGEEVA, S. P. 1963. Conodonts from the Lower Ordovician of the Leningrad region. Paleontologicheskiy Zhurnal, Akademiya Nauk SSSR, 2, 93-108. [In Russian].

SERPAGLI, E. 1967. I conodonti dell'Ordoviciano Superiore (Ashgilliano) delle Alpi Carniche. Bollettino della Società Paleontologica Italiana, 13, 17-98.

SKOGLUND, R. 1963. Uppermost Viruan and Lower Harjuan (Ordovician) stratigraphy of Västergötland and Lower Harjuan graptolite faunas of central Sweden. Bulletin of the Geological Institutions of the University of Uppsala, 42, 1-55.

STAUFFER, C. R. 1935. Conodonts of the Glenwood beds. Geological Society of America Bulletin, 46, 125-168.

STRAHAN, A., CANTRILL, T. C., DIXON, E. E. L. and THOMAS, H. H. 1907. The geology of the South Wales coalfield. Part VII. The country around Ammanford. Memoirs of the Geological Survey of Great Britain. England and Wales, $246 \mathrm{pp}$.

and JONES O. T. 1914. The geology of the South Wales coalfield. Part XI. The country around Haverfordwest. Memoirs of the Geological Survey of Great Britain. England and Wales, $261 \mathrm{pp}$.

SWEET, W. C. 1979a. Conodonts and conodont biostratigraphy of post-Tyrone Ordovician rocks of the Cincinnati region. US Geological Survey Professional Paper, 1066-G, G1G26.

- 1979b. Late Ordovician conodonts and biostratigraphy of the western Midcontinent Province. Brigham Young University Geology Studies, 26, 45-74.

1983. Conodont biostratigraphy of Fite Formation and Viola Group. 23-51. In AMSDEN, T. W. and SWEET, W. C. (ed.). Upper Bromide Formation and Viola Group (Middle and Upper Ordovician) in eastern Oklahoma. Oklahoma Geological Survey Bulletin, 132, 76 pp.

_ and BERGSTRÖM, S. M. 1984. Conodont provinces and biofacies of the Late Ordovician. 69-87. In CLARK, D. L. (ed.). Conodont biofacies and provincialism, Geological Society of America Special Paper, 196, 340 pp.

- THOMPSON, T. T. and SATTERFIELD, I. R. 1975. Conodont stratigraphy of the Cape Limestone (Maysvillian) of eastern Missouri. Missouri Department of Natural Resources, Missouri Geological Survey, Report of Investigations, 57, 1-60.

VANDENBROUCKE, T. R. A., RICKARDS, B. and VERNIERS, J. 2005. Upper Ordovician chitinozoan biostratigraphy from the type Ashgill area (Cautley district) 
and the Pus Gill section (Dufton district, Cross Fell Inlier), Cumbria, northern England. Geological Magazine, 142, 783807.

WILliams, M., ZALASIEWICS, J. A., DAVIERS, J. R. and WATERS, R. A. 2008. Integrated Upper Ordovician graptolite-chitinozoan biostratigraphy of the Cardigan and Whitland areas, southwest Wales. Geological Magazine, 145, 199-214.

VIIRA, V. 1974. Ordovician conodonts of the East Baltic. Valgus, Tallinn, 143 pp. [In Russian with English summary].

WALlisER, O. H. 1964. Conodonten des Silurs. Abhandlungen der Hessischen Landesamtes Bodenforschung, 41, 1-106.

WEBERS, G. F. 1966. The Middle and Upper Ordovician conodont faunas of Minnesota. Minnesota Geological Survey Special Publication, 4, 1-123.
WEYANT, M., DORÉ, F., LEGALL, J. and PONCET, J. 1977. Un épisode calcaire ashgillien dans l'Est du Massif Armoricaine; incidence sur l'âge des dépôts glacio-marins finiordoviciens. Comptes Rendus de l'Academie des Sciences, Paris, 284(D), 1147-1154.

WILliAMS, A. 1953. The Geology of the Llandeilo district, Carmarthenshire. Quarterly Journal of the Geological Society of London, 108, 177-208.

ZALASIEWICZ, J. A., RUSHTON, A. W. A. and OWEN, A. W. 1995. Late Caradoc graptolite faunal gradients across the Iapetus Ocean. Geological Magazine, 132, 611-617.

ZHANG, S., TARRANT, G. A. and BARNES, C. R. 2011. Upper Ordovician conodont biostratigraphy and the age of the Collingwood Member, southern Ontario, Canada. Canadian Journal of Earth Sciences, 48, 1497-1522. 